\title{
Article \\ Numerical Investigations on Heat Transfer Characteristics of Single Particle and Hybrid Nanofluids in Uniformly Heated Tube
}

\author{
Kunal Sandip Garud (D) and Moo-Yeon Lee *(D) \\ Department of Mechanical Engineering, Dong-A University, 37 Nakdong-Daero 550, Saha-gu, \\ Busan 49315, Korea; 1876936@donga.ac.kr \\ * Correspondence: mylee@dau.ac.kr; Tel.: +82-51-200-7642
}

Citation: Garud, K.S.; Lee, M.-Y.

Numerical Investigations on Heat Transfer Characteristics of Single Particle and Hybrid Nanofluids in Uniformly Heated Tube. Symmetry 2021, 13, 876. https://doi.org/ 10.3390/sym13050876

Academic Editor: Mikhail Sheremet

Received: 21 April 2021

Accepted: 12 May 2021

Published: 14 May 2021

Publisher's Note: MDPI stays neutral with regard to jurisdictional claims in published maps and institutional affiliations.

Copyright: (c) 2021 by the authors. Licensee MDPI, Basel, Switzerland. This article is an open access article distributed under the terms and conditions of the Creative Commons Attribution (CC BY) license (https:// creativecommons.org/licenses/by/ $4.0 /)$.

\begin{abstract}
In the present study, the heat transfer characteristics, namely, heat transfer coefficient, Nusselt number, pressure drop, friction factor and performance evaluation criteria are evaluated for water, $\mathrm{Al}_{2} \mathrm{O}_{3}$ and $\mathrm{Al}_{2} \mathrm{O}_{3} / \mathrm{Cu}$ nanofluids. The effects of Reynolds number, volume fraction and composition of nanoparticles in hybrid nanofluid are analyzed for all heat transfer characteristics. The single particle and hybrid nanofluids are flowing through a plain straight tube which is symmetrically heated under uniform heat flux condition. The numerical model is validated for Nusselt number within $7.66 \%$ error and friction factor within $8.83 \%$ error with corresponding experimental results from the previous literature study. The thermophysical properties of hybrid nanofluid are superior to the single particle nanofluid and water. The heat transfer coefficient, Nusselt number and pressure drop show increasing trend with increase in the Reynolds number and volume fraction. The friction factor shows the parabolic trend, and the performance evaluation criteria shows small variations with change in Reynolds number. However, both friction factor and performance evaluation criteria have increased with increase in the volume fraction. The $2.0 \% \mathrm{Al}_{2} \mathrm{O}_{3} / \mathrm{Cu}$ with equal composition of both nanoparticles $(50 / 50 \%)$ have presented superior heat transfer characteristics among all working fluids. Further, the heat transfer characteristics of $2.0 \% \mathrm{Al}_{2} \mathrm{O}_{3} / \mathrm{Cu}$ hybrid nanofluid are enhanced by changing the nanoparticle compositions. The performance evaluation criteria for $2.0 \% \mathrm{Al}_{2} \mathrm{O}_{3}, 2.0 \%$ $\mathrm{Al}_{2} \mathrm{O}_{3} / \mathrm{Cu}(50 / 50 \%), 2.0 \% \mathrm{Al}_{2} \mathrm{O}_{3} / \mathrm{Cu}(75 / 25 \%)$ and $2.0 \% \mathrm{Al}_{2} \mathrm{O}_{3} / \mathrm{Cu}(25 / 75 \%)$ are evaluated as 1.08 , $1.11,1.10$ and 1.12 , respectively.
\end{abstract}

Keywords: heat transfer characteristics; hybrid nanofluid; performance evaluation criteria; single particle nanofluid; uniformly heated tube

\section{Introduction}

Currently, energy saving in thermal systems has grabbed considerable attention to reduce the heat losses and improve the heat transfer performance [1]. Due to restrictions on the further improvement in the thermophysical properties of conventional working fluids, the research trend is drastically shifting towards nanofluids applications in heat transfer systems [2]. Numerous studies were reported on heat transfer applications of nanofluids in the thermal systems such as tubes.

Firoozi et al. have conducted a numerical study to investigate the heat transfer and flow characteristics of $\mathrm{Al}_{2} \mathrm{O}_{3}$ /water nanofluid flowing through tubes incorporated with various dimple configurations [3]. Ledari et al. have investigated the heat transfer and friction factor characteristics of oil based $\mathrm{CuO}$ and $\mathrm{Fe}_{3} \mathrm{O}_{4}$ nanofluids flowing through the U-tube under the influence of various mass concentrations, flow rates and inclination angles [4]. Chaurasia and Sarviya have conducted experimental and numerical studies to analyze the thermal hydraulic and entropy generation performances of nanofluid flowing through helical screw insert tube with single and double strips [5]. Ying et al. have concluded that $\mathrm{Al}_{2} \mathrm{O}_{3}$ / water nanofluid with $0.063 \%$ mass concentration shows improvement in heat transfer coefficient and Nusselt number by $7.29 \%$ and $6.90 \%$, respectively 
under the cosine heat flux condition and that by $7.25 \%$ and $6.85 \%$, respectively under the Gaussian-cosine heat flux condition [6]. Saedodin et al. have compared the heat transfer performances of $\mathrm{SiO}_{2}, \mathrm{Al}_{2} \mathrm{O}_{3}, \mathrm{CuO}$ and $\mathrm{TiO}_{2}$ nanofluids flowing through the straight tube with twisted turbulators [7]. Kristiawan et al. have investigated the thermal and friction factor characteristics of helical microfin tube comprises of $\mathrm{TiO}_{2}$ / water nanofluid with various volume concentrations [8]. Tiwari et al. have compared thermal characteristics of triple tube heat exchanger with porous plate, twisted tape and rib type inserts using $\mathrm{WO}_{3}$ /water nanofluid [9]. Shahsavar et al. have proposed PVT system with rifled serpentine tube comprises of three ribs and six ribs as the replacement of plain serpentine tube [10]. Mukherjee et al. have presented $94 \%$ enhancement in forced convective flow boiling heat transfer of $\mathrm{Al}_{2} \mathrm{O}_{3}$ / water nanofluid flowing through a horizontal tube compared to water [11]. Heyhat et al. have analyzed the heat transfer and pressure drop characteristics of $\mathrm{SiO}_{2}$ / water nanofluid flowing through a conically coiled tube considering the effects of volume concentrations, cone angle and cone pitch [12]. Ho et al. have experimentally and numerically explored the cooling performance characteristics of $\mathrm{Al}_{2} \mathrm{O}_{3} /$ water nanofluid flowing through a copper tube under constant heat flux condition [13]. Sun et al. have compared the convective heat transfer and flow characteristics of smooth and inner grooved copper tubes considering flow of $\mathrm{Fe}_{2} \mathrm{O}_{3}$ / water nanofluid [14]. Behzadnia et al. have proposed an optimum geometry of rectangular corrugated tube to maximize the heat transfer efficiency using $\mathrm{Al}_{2} \mathrm{O}_{3}$ /water nanofluid [15]. Kaood et al. have investigated the thermal, hydraulic and energy performances of $\mathrm{Al}_{2} \mathrm{O}_{3}$ /water and $\mathrm{SiO}_{2}$ / water nanofluids flowing through a corrugated tube with curved ribs, rectangular, triangular and trapezoidal geometries [16]. Safaei et al. have numerically investigated the influences of volume fraction, particle size and velocity on pressure and friction factor of $\mathrm{Cu} /$ water nanofluid flow inside a pipe bend [17]. Qureshi et al. have investigated the heat transfer and entropy characteristics of Williamson nanofluid based on magnetohydrodynamics [18].

Yildirim et al. have proved that $\mathrm{SiO}_{2}$ and $\mathrm{Cu}$ based mono and hybrid nanofluids show $15 \%$ better thermal performance compared with water for U-tube incorporated in an evacuated tube solar collector [19]. Saleh and Sundar have presented improvement in the thermal performance factor, Nusselt number, frictional entropy generation, friction factor and exergy efficiency by $14.19 \%, 19.67 \%, 210.6 \%, 15.11 \%$ and $17.54 \%$, respectively and $22.93 \%$ decrease in the thermal entropy generation for $\mathrm{Fe}_{3} \mathrm{O}_{4} /$ nanodiamond nanofluid compared to base fluid for circular tube [20]. Ramadhan et al. have shown the behavior of Nusselt number and friction factor of $\mathrm{TiO}_{2} / \mathrm{SiO}_{2}$ nanofluid flowing through a plain tube for various Reynolds number and volume concentrations of nanofluid [21]. Han et al. have investigated the heat transfer performances of $\mathrm{n}$-decane- $\mathrm{ZnO}$ nanofluid which is pressurized below supercritical pressure and flowing through a horizontal tube. The heat transfer and Nusselt number of n-decane- $\mathrm{ZnO}$ nanofluid have increased $20 \%$ under a supercritical pressure [22]. Akbar et al. have concluded that the hybrid nanofluid of alumina and titanium with low volume concentrations presents 30\% enhanced heat transfer compared to water for a horizontal heated tube [23]. Azmi et al. have studied the effect of various composition ratios of $\mathrm{TiO}_{2} / \mathrm{SiO}_{2}$ hybrid nanofluid on thermal-hydraulic performance of flow in a tube with wire coils [24]. Moldoveanu et al. have experimentally investigated the thermal conductivity of $\mathrm{Al}_{2} \mathrm{O}_{3} / \mathrm{SiO}_{2}$ hybrid nanofluid under the influence of temperature and volume fraction [25]. Yang et al. have concluded that $\mathrm{Al}_{2} \mathrm{O}_{3} / \mathrm{TiO}_{2}$ hybrid nanofluid exhibits superior Nusselt number, friction factor and performance evaluation criteria compared to $\mathrm{Al}_{2} \mathrm{O}_{3} / \mathrm{ZrO}_{2}$ hybrid nanofluid for a parallel channel flow under the same pumping power [26]. Adriana has presented the enhancement of $12 \%$ in thermal conductivity of hybrid nanofluid and develop the Nusselt number correlation in terms of Reynolds number, Prandtl number and volume fraction [27].

There are numerous studies in the open literature which show the suitability of single particle nanofluids in heat transfer applications. The research work in heat transfer enhancement using hybrid nanofluids is comparatively less. Specifically, in the field of circular tubes used for solar receiver/collectors and multitube heat exchanger, the 
investigations on the trade-off comparison between heat transfer characteristics considering different compositions of hybrid nanoparticles is not explored detailly and compared with single particle nanofluid and conventional working fluid results. There are very few studies which present the comprehensive comparison of conventional working fluid, single particle, and hybrid nanofluids based on heat transfer characteristics considering the effect of Reynolds number, volume fraction and composition of hybrid nanoparticles. The objective of the present study is to compare heat transfer coefficient, Nusselt number, pressure drop, friction factor and performance evaluation criteria as heat transfer characteristics for water, $\mathrm{Al}_{2} \mathrm{O}_{3}$ and $\mathrm{Al}_{2} \mathrm{O}_{3} / \mathrm{Cu}$ nanofluids in a plain straight tube under symmetrical and uniform heat flux condition. The comparison is carried out for various Reynolds number, volume fractions and compositions of $\mathrm{Al}_{2} \mathrm{O}_{3} / \mathrm{Cu}$ nanoparticles. The novelty of the present work is to summarize the effects on heat transfer characteristics of hybrid nanofluid by mixing two nanoparticles, one with higher stability and lower thermal conductivity $\left(\mathrm{Al}_{2} \mathrm{O}_{3}\right)$ and other one with lower stability and higher thermal conductivity $(\mathrm{Cu})$ for different compositions of both nanoparticles. In addition, these results could give a guideline on how much propositions of both nanoparticles could be mixed in hybrid nanofluid to achieve the effective balance between heat transfer and pressure drop.

\section{Numerical Method}

The numerical model based on computational fluid dynamics (CFD) is employed to analyze the heat transfer characteristics including thermal and flow attributes of single particle and hybrid nanofluids flow in uniformly heater tube. The tube with water, single particle and hybrid nanofluids as working fluids is considered under the constant heat flux condition. The constant heat flux applied on a tube is symmetrically distributed on the surface of tube to analyze the heat transfer characteristics of single particle and hybrid nanofluids. The 3D computational domain of tube is shown in Figure 1. The 3D computational domain is considered to account the effect of uniform heat flux boundary condition [28]. The tube has length of $1500 \mathrm{~mm}$, inner diameter of $16 \mathrm{~mm}$ and outer diameter of $19 \mathrm{~mm}$. The tube is made up of copper. The physical properties of copper considered for the numerical analysis as, density of $8940 \mathrm{~kg} / \mathrm{m}^{3}$, specific heat of $376.8 \mathrm{~J} / \mathrm{kg} \cdot \mathrm{K}$ and thermal conductivity of $401 \mathrm{~W} / \mathrm{m} \cdot \mathrm{K}$ [29]. The constant heat flux of $7957 \mathrm{~W} / \mathrm{m}^{2}$ is applied uniformly on the tube outer surface [30]. To analyze the heat transfer characteristics of water and nanofluids, the tube under constant heat flux condition is simulated in ANSYS commercial software. The meshing with tetrahedron mesh elements and five different sizes is generated for the considered computational domain to show the mesh independency of the simulated results [31]. The Nusselt number and friction factor are simulated for five different mesh element numbers ranging from 100,000 to 700,000. The variation of Nusselt number $(\mathrm{Nu})$ and friction factor $(\mathrm{f})$ for various mesh element numbers is presented in Figure 2. The variation of the simulated results of Nusselt number and friction factor are within $\pm 1 \%$ beyond the mesh element number of 425,691 . After this mesh element number, the simulated results are independent of number of mesh elements. Hence, the mesh element number of 425,691 corresponding to the sizing of $2 \mathrm{~mm}$ is selected as the final meshing configuration for the numerical analysis on the considered computational domain. The inflation layers are employed on the fluid domain to account the effect of boundary layer.

The continuity, momentum and energy equations are solved for the considered tube with flow of various working fluids to simulate the thermal and flow characteristics [32,33].

Continuity equation

$$
\nabla \cdot(\rho U)=0
$$

Momentum equation

$$
\nabla \cdot(\rho U U)=-\nabla P+\nabla \tau
$$


Stress tensor $\tau$ is expressed in terms of strain rate as follows

$$
\tau=\mu\left(\nabla U+(\nabla U)^{T}-\frac{2}{3} \delta \nabla \cdot U\right)
$$

Energy equation

$$
\nabla \cdot(\rho U h)=\nabla \cdot(k \nabla T)+\tau: \nabla U
$$

Here, $\rho\left(\mathrm{kg} / \mathrm{m}^{3}\right)$ is density, $U(\mathrm{~m} / \mathrm{s})$ is velocity, $P(\mathrm{~Pa})$ is static pressure, $\mu(\mathrm{Pa} \cdot \mathrm{s})$ is viscosity, $h(\mathrm{~J})$ is enthalpy, $k(\mathrm{~W} / \mathrm{m} \cdot \mathrm{K})$ is thermal conductivity and $\nabla T$ is temperature gradient.

Heat flux
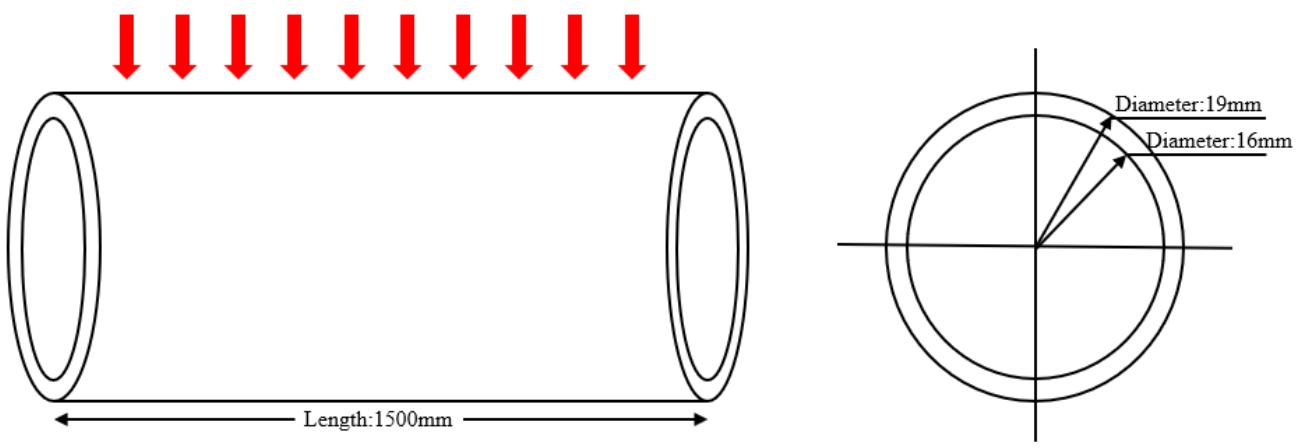

Figure 1. 3D computational domain of tube.

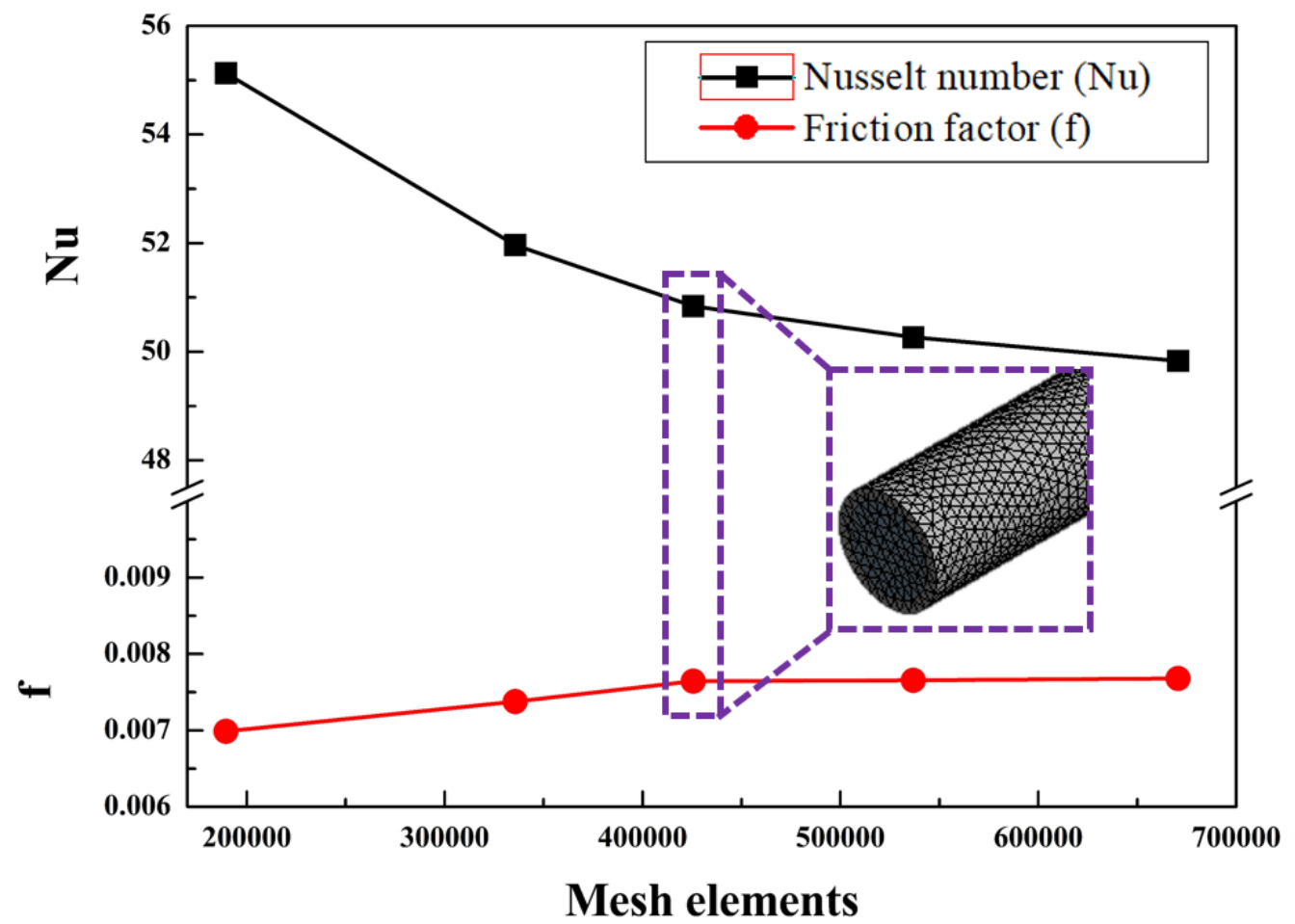

Figure 2. Variation of Nusselt number and friction factor for various mesh element numbers.

The k- $\varepsilon$ turbulence model could be expressed by Equations (5) and (6), respectively [34].

$$
\begin{gathered}
\frac{\partial\left(\rho U_{i} k\right)}{\partial x_{i}}=\frac{\partial}{\partial x_{i}}\left[\left(v+\frac{v_{t}}{\sigma_{k}}\right) \frac{\partial k}{\partial x_{i}}\right]+P_{k}-\rho \varepsilon \\
\frac{\partial\left(\rho U_{i} \varepsilon\right)}{\partial x_{i}}=\frac{\partial}{\partial x_{i}}\left[\left(v+\frac{v_{t}}{\sigma_{\varepsilon}}\right) \frac{\partial \varepsilon}{\partial x_{i}}\right]+\rho C_{1} S \varepsilon-\rho C_{2} \frac{\varepsilon^{2}}{k+\sqrt{v \varepsilon}}
\end{gathered}
$$


Here, $k$ presents the turbulence kinetic energy, $v_{t}$ presents the turbulent eddy viscosity, $\varepsilon$ presents the dissipation rate of turbulence energy, $S$ presents the modulus of the mean rate of strain tensor, $P_{k}$ stands for the shear production of turbulent kinetic energy $\sigma_{k}$ and $\sigma_{\varepsilon}$ are 1 and 1.2 , respectively.

The boundary conditions considered in the numerical analysis are constant heat flux of $7957 \mathrm{~W} / \mathrm{m}^{2}$ at tube wall with symmetrical distribution, velocity inlet with various Reynolds number of working fluid and pressure outlet. The working fluids considered in the numerical analysis are conventional fluid water, single particle nanofluid namely, $\mathrm{Al}_{2} \mathrm{O}_{3}$ and hybrid nanofluid namely, $\mathrm{Al}_{2} \mathrm{O}_{3} / \mathrm{Cu}$. The Reynolds number is ranging from 2000 to 12000 and inlet fluid temperature is considered as $298.15 \mathrm{~K}$ in the numerical analysis. The thermophysical properties of single particle and hybrid nanofluids are evaluated using the thermal properties of base fluid and respective nanoparticles. Three volume fractions of $0.5 \%, 1.0 \%$ and $2.0 \%$ are considered in the present numerical analysis. In case of hybrid nanofluids, the composition of both nanoparticles is mixed in the proportions of $75 / 25 \%$, $50 / 50 \%$ and $25 / 75 \%$. While solving equations using the considered boundary conditions, it is assumed that the flow is uniform, steady and incompressible [35]. The laminar and standard $k-\varepsilon$ turbulence models are considered for the numerical analysis. The convergence criteria are selected as $10^{-8}$ for all equations.

\section{Thermophysical Properties of Nanofluids}

The properties of base fluid, water and considered nanoparticles, $\mathrm{Al}_{2} \mathrm{O}_{3}$ and $\mathrm{Cu}$ are depicted in Table $1[36,37]$. The considered $\mathrm{Al}_{2} \mathrm{O}_{3}$ and $\mathrm{Cu}$ nanoparticles are of spherical shape with $100 \mathrm{~nm}$ size. The thermophysical properties of single particle nanofluid and hybrid nanofluid are calculated using equations presented in Subsections (a) and (b) based on the depicted properties of basefluid and nanoparticles in Table 1. The widely used models in the open literature are employed to evaluate the thermophysical properties of single particle and hybrid nanofluids. All thermophysical properties are calculated by assuming the constant temperature hence, the temperature effect is neglected [5].

Table 1. Properties of base fluid and nanoparticles.

\begin{tabular}{cccc}
\hline Property & Water & $\mathrm{Al}_{2} \mathbf{O}_{3}$ & $\mathrm{Cu}$ \\
\hline Density $\left(\mathrm{kg} / \mathrm{m}^{3}\right)$ & 998.2 & 3970 & 8300 \\
Specific heat $(\mathrm{J} / \mathrm{kg} \cdot \mathrm{K})$ & 4182 & 765 & 420 \\
Thermal conductivity $(\mathrm{W} / \mathrm{m} \cdot \mathrm{K})$ & 0.6 & 40 & 401 \\
Viscosity $(\mathrm{Pa} \cdot \mathrm{s})$ & 0.001 & - & - \\
\hline
\end{tabular}

(a) Single particle nanofluid properties [38,39];

Volume fraction of nanoparticles in nanofluid

$$
\varnothing=\frac{V_{n p}}{V_{b f}+V_{n p}}
$$

Density of nanofluid

$$
\rho_{n f}=(1-\varnothing) \rho_{b f}+\varnothing \rho_{n p}
$$

Specific heat of nanofluid

$$
C_{p, n f}=\frac{(1-\varnothing) \rho_{b f} C_{p, b f}+\varnothing \rho_{n p} C_{p, n p}}{\rho_{n f}}
$$

Thermal conductivity of nanofluid

$$
\frac{k_{n f}}{k_{b f}}=\frac{\left(k_{n p}+2 k_{b f}\right)-2 \varnothing\left(k_{b f}-k_{n p}\right)}{\left(k_{n p}+2 k_{b f}\right)+\varnothing\left(k_{b f}-k_{n p}\right)}
$$


Viscosity of nanofluid

$$
\mu_{n f}=\mu_{b f} \frac{1}{(1-\varnothing)^{2.5}}
$$

Here, $\varnothing$ is volume fraction of nanoparticles in nanofluid, $V_{b f}(\mathrm{~L})$ is volume of basefluid, $V_{n p}(\mathrm{~L})$ is volume of nanoparticles $=\frac{m_{n p}}{\rho_{n p}}, m_{n p}(\mathrm{~kg})$ is mass of nanoparticles, $\rho_{n p}\left(\mathrm{~kg} / \mathrm{m}^{3}\right)$ is density of nanoparticles, $\rho_{n f}\left(\mathrm{~kg} / \mathrm{m}^{3}\right)$ is density of nanofluid, $\rho_{b f}\left(\mathrm{~kg} / \mathrm{m}^{3}\right)$ is density of base fluid, $C_{p, n f}(\mathrm{~J} / \mathrm{kg} \cdot \mathrm{K})$ is specific heat of nanofluid, $C_{p, b f}(\mathrm{~J} / \mathrm{kg} \cdot \mathrm{K})$ is specific heat of basefluid, $C_{p, n p}(\mathrm{~J} / \mathrm{kg} \cdot \mathrm{K})$ is specific heat of nanoparticles, $k_{n f}(\mathrm{~W} / \mathrm{m} \cdot \mathrm{K})$ is thermal conductivity of nanofluid, $k_{b f}(\mathrm{~W} / \mathrm{m} \cdot \mathrm{K})$ is thermal conductivity of basefluid, $k_{n p}(\mathrm{~W} / \mathrm{m} \cdot \mathrm{K})$ is thermal conductivity of nanoparticle, $\mu_{n f}(\mathrm{~Pa} \cdot \mathrm{s})$ is viscosity of nanofluid and $\mu_{b f}(\mathrm{~Pa} \cdot \mathrm{s})$ is viscosity of basefluid.

(b) Hybrid nanofluid properties [40];

Volume fraction of nanoparticles in nanofluid

$$
\varnothing_{h n f}=\varnothing_{n p 1}+\varnothing_{n p 2}
$$

Density of hybrid nanofluid

$$
\rho_{h n f}=\varnothing_{n p 1} \rho_{n p 1}+\varnothing_{n p 2} \rho_{h p 2}+\left(1-\varnothing_{h n f}\right) \rho_{b f}
$$

Specific heat of hybrid nanofluid

$$
C_{p, h n f}=\frac{\varnothing_{n p 1} \rho_{n p 1} C_{p, n p 1}+\varnothing_{n p 2} \rho_{n p 2} C_{p, n p 2}+\left(1-\varnothing_{h n f}\right) \rho_{b f} C_{p, b f}}{\rho_{h n f}}
$$

Thermal conductivity of hybrid nanofluid

$$
k_{h n f}=\frac{\frac{\varnothing_{n p 1} k_{n p 1}+\varnothing_{n p 2} k_{n p 2}}{\varnothing_{h n f}}+2 k_{b f}+2\left(\varnothing_{n p 1} k_{n p 1}+\varnothing_{n p 2} k_{n p 2}\right)-2 \varnothing_{h n f} k_{b f}}{\frac{\varnothing_{n p 1} k_{n p 1}+\varnothing_{n p 2} k_{n p 2}}{\varnothing_{h n f}}+2 k_{b f}-2\left(\varnothing_{n p 1} k_{n p 1}+\varnothing_{n p 2} k_{n p 2}\right)+\varnothing_{h n f} k_{b f}}
$$

Viscosity of hybrid nanofluid

$$
\mu_{h n f}=\mu_{b f} \frac{1}{\left(1-\varnothing_{n p 1}-\varnothing_{n p 2}\right)^{2.5}}
$$

Here, $\varnothing_{h n f}$ is volume fraction of hybrid nanofluid, $\varnothing_{n p 1}$ is volume fraction of nanoparticle1, $\varnothing_{n p 2}$ is volume fraction of nanoparticle2, $\rho_{h n f}\left(\mathrm{~kg} / \mathrm{m}^{3}\right)$ is density of hybrid nanofluid, $\rho_{n p 1}\left(\mathrm{~kg} / \mathrm{m}^{3}\right)$ is density of nanoparticle1, $\rho_{n p 2}\left(\mathrm{~kg} / \mathrm{m}^{3}\right)$ is density of nanoparticle2, $C_{p, h n f}$ $(\mathrm{J} / \mathrm{kg} \cdot \mathrm{K})$ is specific heat of hybrid nanofluid, $C_{p, n p 1}(\mathrm{~J} / \mathrm{kg} \cdot \mathrm{K})$ is specific heat of nanoparticle1, $C_{p, n p 2}(\mathrm{~J} / \mathrm{kg} \cdot \mathrm{K})$ is specific heat of nanoparticle $2, k_{h n f}(\mathrm{~W} / \mathrm{m} \cdot \mathrm{K})$ is thermal conductivity of hybrid nanofluid, $k_{n p 1}(\mathrm{~W} / \mathrm{m} \cdot \mathrm{K})$ is thermal conductivity of nanoparticle1, $k_{n p 2}(\mathrm{~W} / \mathrm{m} \cdot \mathrm{K})$ is thermal conductivity of nanoparticle 2 and $\mu_{h n f}(\mathrm{~Pa} \cdot \mathrm{s})$ is viscosity of hybrid nanofluid.

The volume fractions of $0.5 \%, 1.0 \%$ and $1.5 \%$ as well as density, specific heat, thermal conductivity and viscosity of water, $\mathrm{Al}_{2} \mathrm{O}_{3}$ and $\mathrm{Cu}$ nanoparticles as shown in Table 1 are imported in Equations (7)-(16) to calculate the density, specific heat, thermal conductivity and viscosity of single particle $\mathrm{Al}_{2} \mathrm{O}_{3}$ and hybrid $\mathrm{Al}_{2} \mathrm{O}_{3} / \mathrm{Cu}$ nanofluids. The calculated properties of $\mathrm{Al}_{2} \mathrm{O}_{3}$ and $\mathrm{Al}_{2} \mathrm{O}_{3} / \mathrm{Cu}$ nanofluids are elaborated in Section 5.2. 


\section{Data Reduction}

The average heat transfer coefficient for the considered heated tube with various working fluids is calculated using Equation (17) [12].

$$
h=\frac{Q}{A\left(T_{s}-T_{f, \text { ave }}\right)}
$$

The heat absorbed by working fluid is calculated using Equation (18) [41,42].

$$
Q=m_{f} c_{p}\left(T_{f, o}-T_{f, i}\right)
$$

The average Nusselt number considering calculated average heat transfer coefficient, hydraulic diameter of tube and thermal conductivity of working fluid is evaluated using Equation (19) [23].

$$
N u=\frac{h D}{k}
$$

Here, $T_{s}(\mathrm{~K})$ presents average temperature of wall surface, $T_{f, o}(\mathrm{~K})$ presents outlet fluid temperature, $T_{f, i}(\mathrm{~K})$ presents inlet fluid temperature, $T_{f, \text { ave }}(\mathrm{K})$ presents average fluid temperature, $D(\mathrm{~mm})$ presents hydraulic diameter, $k(\mathrm{~W} / \mathrm{m} \cdot \mathrm{K})$ presents thermal conductivity of working fluid, $m_{f}(\mathrm{~kg} / \mathrm{s})$ presents mass flow rate of fluid and $c_{p}(\mathrm{~J} / \mathrm{kg} \cdot \mathrm{K})$ presents specific heat of fluid.

The pressure drop of working fluid across the tube is calculated using Equation (20) [43].

$$
\Delta P=P_{f, i}-P_{f, o}
$$

The friction factor for a tube with various working fluids is evaluated using pressure drop, length of tube, hydraulic diameter, density and average velocity as presented by Equation (21) [21,23].

$$
f=\frac{\Delta P}{\frac{L}{D} \times \frac{\rho U^{2}}{2}}
$$

Here, $\Delta P(\mathrm{~Pa})$ is pressure drop, $P_{f, i}(\mathrm{~Pa})$ is inlet fluid pressure, $P_{f, o}(\mathrm{~Pa})$ is outlet fluid pressure, $f$ is friction factor, $L(\mathrm{~mm})$ is length of tube, $\rho\left(\mathrm{kg} / \mathrm{m}^{3}\right)$ is density of fluid and $U(\mathrm{~m} / \mathrm{s})$ is the average velocity.

Considering the Nusselt numbers and friction factors of base fluid and nanofluids, the performance evaluation criteria is defined as presented by Equation (22) [44].

$$
P E C=\frac{\left(\frac{N u_{n f}}{N u_{b f}}\right)}{\left(\frac{f_{n f}}{f_{b f}}\right)^{\frac{1}{3}}}
$$

where $N u_{n f}$ is Nusselt number of nanofluid, $N u_{b f}$ is Nusselt number of basefluid, $f_{n f}$ is friction factor of nanofluid and $f_{n f}$ is friction factor of nanofluid.

\section{Results and Discussion}

\subsection{Validation}

The numerical model based on CFD is validated with the experimental results presented by Hamid et al. for the same geometry (dimensions and structure) and boundary conditions [30]. The experimental and numerical results of Nusselt number and friction factor are compared as the heat transfer characteristics for various Reynolds number. The comparison of Nusselt number and friction factor for previous experimental study and present numerical model for various Reynolds number (Re) is depicted in Figure 3. The comparison is presented for water/EG flow in the considered tube geometry under the constant heat flux of $7957 \mathrm{~W} / \mathrm{m}^{2}$. The trends of experimental and numerical results are sim- 
ilar, Nusselt number increases, and friction factor decreases with increase in the Reynolds number. The average deviation between the experimental and numerical results of Nusselt number is $7.66 \%$ and that of friction factor is $8.83 \%$ for all considered Reynolds number variation. The presented numerical model based on CFD approach is validated within $10 \%$ error with previous experimental results for heat transfer characteristics. Therefore, the validated numerical model could be used for the detail comparison of heat transfer characteristics of single particle and hybrid nanofluids flow in uniformly heated plain straight tube.

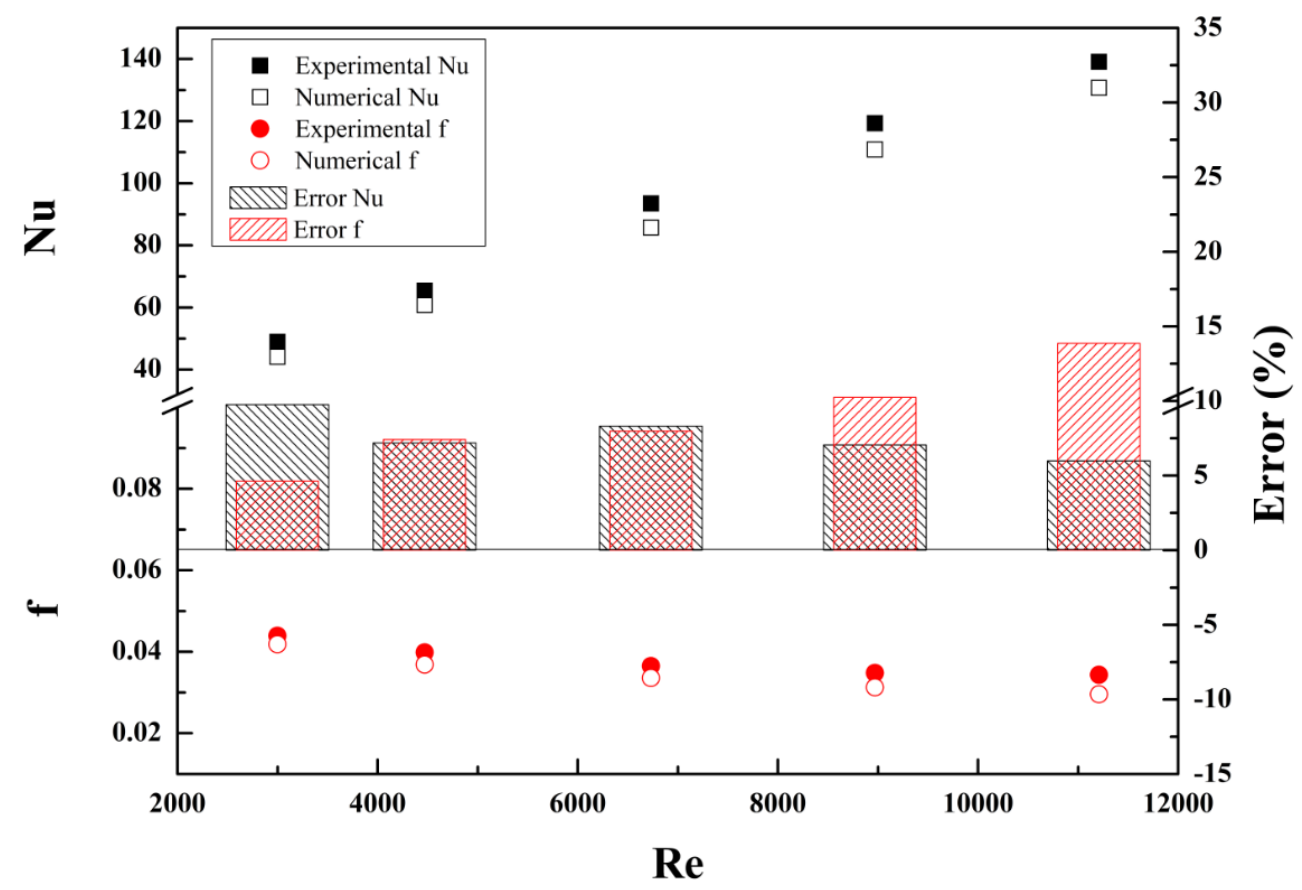

Figure 3. Comparison of Nusselt number and friction factor for previous experimental study and present numerical model for various Reynolds numbers.

\subsection{Comparison of Nanofluid Properties}

The thermophysical properties namely, density, specific heat, thermal conductivity and viscosity of single particle and hybrid nanofluids are calculated using equations presented in Section 3. The calculated thermophysical properties of single particle and hybrid nanofluids are depicted in Table 2 . In case of hybrid nanofluid, the composition of $\mathrm{Al}_{2} \mathrm{O}_{3}$ and $\mathrm{Cu}$ are mixed in the proposition of 50/50\%. The density and thermal conductivity of hybrid nanofluid are higher than those of single particle nanofluid for all volume fractions. This is because the $\mathrm{Cu}$ nanoparticles have higher density and thermal conductivity compared to $\mathrm{Al}_{2} \mathrm{O}_{3}$ nanoparticles. However, the specific heat of single particle nanofluid is superior to the specific heat of hybrid nanofluid for all volume fractions due to lower specific heat of $\mathrm{Cu}$ nanoparticles compared to specific heat of $\mathrm{Al}_{2} \mathrm{O}_{3}$ nanoparticles. There is no difference for the viscosity of single particle and hybrid nanofluids for each volume fraction because the viscosity of base fluid is same for both single particle and hybrid nanofluids. However, the viscosity of nanofluids increases with increase in the volume fraction. The density and thermal conductivity of single particle and hybrid nanofluids have increased and the specific heat has decreased with increase in the volume fraction. This is because the density and thermal conductivity of nanoparticles enhances, and the specific heat of nanoparticles reduces with increase in volume fraction of nanoparticle in both single particle and hybrid nanofluids. The density and thermal conductivity of nanoparticles are higher than water which shows superior density and thermal conductivity of nanofluids than base fluid which further increases with increase in the volume fraction. Whereas the specific heat of nanoparticles is lower than the water which results into lower specific heat 
of nanofluids than base fluid and further decreases with increase in the volume fraction. This is because the water has lower density, lower thermal conductivity and higher specific heat compared to $\mathrm{Al}_{2} \mathrm{O}_{3}$ and $\mathrm{Cu}$ nanoparticles. The density enhances by $4.4 \%$ and $7.5 \%$ for $\mathrm{Al}_{2} \mathrm{O}_{3}$ and $\mathrm{Al}_{2} \mathrm{O}_{3} / \mathrm{Cu}$ nanofluids, respectively with increase in volume fraction from $0.5 \%$ to $2.0 \%$. The thermal conductivity improves by $4.3 \%$ and $6.1 \%$ for $\mathrm{Al}_{2} \mathrm{O}_{3}$ and $\mathrm{Al}_{2} \mathrm{O}_{3} / \mathrm{Cu}$ nanofluids, respectively with increase in volume fraction from $0.5 \%$ to $2.0 \%$. The specific heat of $\mathrm{Al}_{2} \mathrm{O}_{3}$ and $\mathrm{Al}_{2} \mathrm{O}_{3} / \mathrm{Cu}$ nanofluids decease by $4.6 \%$ and $7.3 \%$, respectively with increase in volume fraction from $0.5 \%$ to $2.0 \%$. The viscosity increases by $3.9 \%$ for $\mathrm{Al}_{2} \mathrm{O}_{3}$ and $\mathrm{Al}_{2} \mathrm{O}_{3} / \mathrm{Cu}$ nanofluids with increase in volume fraction from $0.5 \%$ to $2.0 \%$. Addition of $\mathrm{Cu}$ nanoparticle along with $\mathrm{Al}_{2} \mathrm{O}_{3}$ nanoparticle improves the thermophysical properties of hybrid nanofluid compared to single particle nanofluid.

Table 2. Properties of base fluid and nanoparticles.

\begin{tabular}{ccccc}
\hline Nanofluid & $\begin{array}{c}\text { Density } \\
\left(\mathbf{k g} / \mathbf{m}^{3}\right)\end{array}$ & $\begin{array}{c}\text { Specific Heat } \\
\mathbf{( J / k g} \cdot \mathbf{K})\end{array}$ & $\begin{array}{c}\text { Thermal Conductivity } \\
(\mathbf{W} / \mathbf{m} \cdot \mathbf{K})\end{array}$ & Viscosity (Pa.s) \\
\hline $0.5 \% \mathrm{Al}_{2} \mathrm{O}_{3}$ & 1013.059 & 4115.047 & 0.608648 & 0.001013 \\
$0.5 \% \mathrm{Al}_{2} \mathrm{O}_{3} / \mathrm{Cu}$ & 1023.884 & 4072.637 & 0.612030 & 0.001013 \\
$1.0 \% \mathrm{Al}_{2} \mathrm{O}_{3}$ & 1027.918 & 4050.029 & 0.617380 & 0.001025 \\
$1.0 \% \mathrm{Al}_{2} \mathrm{O}_{3} / \mathrm{Cu}$ & 1049.568 & 3968.626 & 0.624304 & 0.001025 \\
$2.0 \% \mathrm{Al}_{2} \mathrm{O}_{3}$ & 1057.636 & 3925.475 & 0.635098 & 0.001052 \\
$2.0 \% \mathrm{Al}_{2} \mathrm{O}_{3} / \mathrm{Cu}$ & 1100.936 & 3775.164 & 0.649614 & 0.001052 \\
\hline
\end{tabular}

\subsection{Comparison of Heat Transfer Characteristics}

In this section, the heat transfer characteristics including thermal attributes of heat transfer coefficient and Nusselt number and flow attributes of pressure drop and friction factor are compared for single particle and hybrid nanofluids. In addition, the comparison of single particle and hybrid nanofluids is extended for the combined thermal and flow attributes by defining the parameter namely, performance evaluation criteria (PEC).

\subsubsection{Heat Transfer Coefficient}

The heat transfer coefficient $(\mathrm{h})$ of water, single particle and hybrid nanofluids flow inside tube for various volume fractions and Reynolds number is presented in Figure 4. The heat transfer coefficients of all working fluids have increased with increase in the Reynolds number and the variation trends are linear. Saedodin et al. have also presented the increasing linear trend of heat transfer coefficient for various working fluids flow inside tube with Reynolds number [7]. The turbulence increases with increase in the Reynolds number for all working fluids. The heat transfer rate increases as the turbulence increases. Higher turbulence at higher Reynolds number of working fluids absorbs higher heat and presents higher heat transfer rate compared with lower turbulence at lower Reynolds number of working fluids. Therefore, the heat transfer coefficient of working fluids is higher at the higher Reynolds number and lower at lower Reynolds number. The heat transfer coefficient of single particle and hybrid nanofluids for all volume fractions are higher than water because of improved thermophysical properties of single particle and hybrid nanofluids compared to water. The heat transfer coefficient improves further with increase in the volume fractions. In addition, for the same volume fraction, the heat transfer coefficient of hybrid nanofluid is better than the single particle nanofluid due to addition of $\mathrm{Cu}$ nanoparticles with higher thermal conductivity in hybrid nanofluid. The heat transfer coefficients of $\mathrm{Al}_{2} \mathrm{O}_{3}$ nanofluid are higher by $2.5 \%, 4.9 \%$ and $10.2 \%$ and those of $\mathrm{Al}_{2} \mathrm{O}_{3} / \mathrm{Cu}$ nanofluids are higher by $3.6 \%, 7.2 \%$ and $14.8 \%$ for volume fractions of $0.5 \%, 1.0 \%$ and $2.0 \%$, respectively compared with water. The $\mathrm{Al}_{2} \mathrm{O}_{3} / \mathrm{Cu}$ nanofluid with $2.0 \%$ volume fraction shows highest heat transfer coefficient among all working fluids. The heat transfer coefficient increases by $546.1 \%$ for $\mathrm{Al}_{2} \mathrm{O}_{3} / \mathrm{Cu}$ nanofluid with $2.0 \%$ volume fraction when the Reynolds number increases from 2000 to 12,000 . 


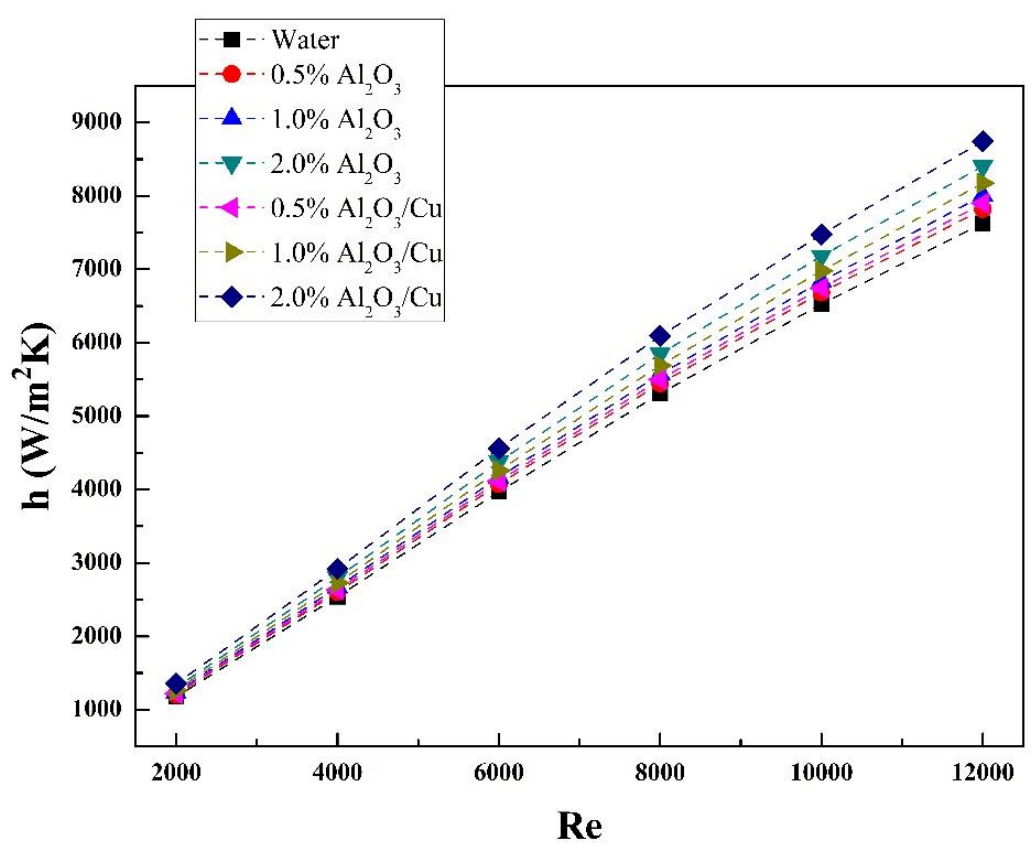

Figure 4. Heat transfer coefficient of water, single particle and hybrid nanofluids flow inside tube for various volume fractions and Reynolds number.

\subsubsection{Nusselt Number}

The comparison of Nusselt number of various working fluids with Reynolds number is presented in Figure 5. The Nusselt number depends on the heat transfer coefficient hence, the variation trend of Nusselt number is similar as of heat transfer coefficient for each working fluid. The Nusselt number increases linearly with Reynolds number for all working fluids because of increase in the turbulence with increase in the Reynolds number. The Nusselt number of hybrid nanofluid is better than the single particle nanofluid for the same volume fraction due to higher heat transfer coefficient of hybrid nanofluid compared to single particle nanofluid. In addition, due to the improved thermophysical properties of nanofluids by dispersion of nanoparticles in water, the Nusselt number of single particle and hybrid nanofluids are superior compared to water. Addition of solid nanoparticles into water has enhanced the thermal conductivity which improves continuously as larger amounts of nanoparticles are dispersed, which results in increase in heat transfer coefficient. Therefore, the Nusselt number increases with increase in the volume fraction for both single particle and hybrid nanofluids. The Nusselt numbers of $50.83,52.13,53.36,56.02,52.65,54.49$ and 58.29 are evaluated for water, $0.5 \% \mathrm{Al}_{2} \mathrm{O}_{3}, 1.0 \%$ $\mathrm{Al}_{2} \mathrm{O}_{3}, 2.0 \% \mathrm{Al}_{2} \mathrm{O}_{3}, 0.5 \% \mathrm{Al}_{2} \mathrm{O}_{3} / \mathrm{Cu}, 1.0 \% \mathrm{Al}_{2} \mathrm{O}_{3} / \mathrm{Cu}$ and $2.0 \% \mathrm{Al}_{2} \mathrm{O}_{3} / \mathrm{Cu}$, respectively at Reynolds number of 12000 . The $2.0 \% \mathrm{Al}_{2} \mathrm{O}_{3} / \mathrm{Cu}$ nanofluid presents superior value of Nusselt number for all Reynolds number compared to other working fluids. The Nusselt number of $2.0 \% \mathrm{Al}_{2} \mathrm{O}_{3} / \mathrm{Cu}$ nanofluid increases from 9.02 to 58.29 as the Reynolds number increases from 2000 to 12000 . Firoozi et al. have shown the Nusselt number ranging from 10 to 40 for the variation of Reynolds number up to 5000 [3]. Torii and Hajime have reported the Nusselt number enhancement for graphene-oxide nanofluid as twice than water for horizontal circular tube under constant heat flux [45].

\subsubsection{Pressure Drop}

The variation of pressure drop for water, single particle and hybrid nanofluids with various volume fractions and Reynolds number is depicted in Figure 6. The pressure drop increases with increase in the Reynolds number because the turbulence increases as the Reynolds number increases for all working fluids. However, the variation trend of pressure drop with Reynolds number is not linear for all working fluids. The variation trend is exponential as confirmed by many research studies in the open literature. Kristiawan et al. 
have presented the exponential (non-linear) variation of pressure drop with Reynolds number and pressure drop increases with Reynolds number for various working fluids flow in a tube [8]. Pressure drop of single particle and hybrid nanofluids are higher than water because the viscosity of single particle and hybrid nanofluids are higher compared to water. In addition, the viscosity of single particle and hybrid nanofluids increases as volume fraction increases due to dispersion of larger volume of nanoparticles into base fluid water. This results into increase of pressure drop with volume fraction for single particle and hybrid nanofluids. Despite of the same viscosity of single particle and hybrid nanofluids at the same volume fraction, the pressure drop for the hybrid nanofluid are lower than the single particle nanofluids for all volume fractions. The pressure drop of $2.0 \% \mathrm{Al}_{2} \mathrm{O}_{3}$ nanofluid is highest among all working fluids. The pressure drops of $2.0 \%$ $\mathrm{Al}_{2} \mathrm{O}_{3}$ nanofluid and $2.0 \% \mathrm{Al}_{2} \mathrm{O}_{3} / \mathrm{Cu}$ nanofluid are higher by $4.5 \%$ and $0.34 \%$, respectively compared to water.

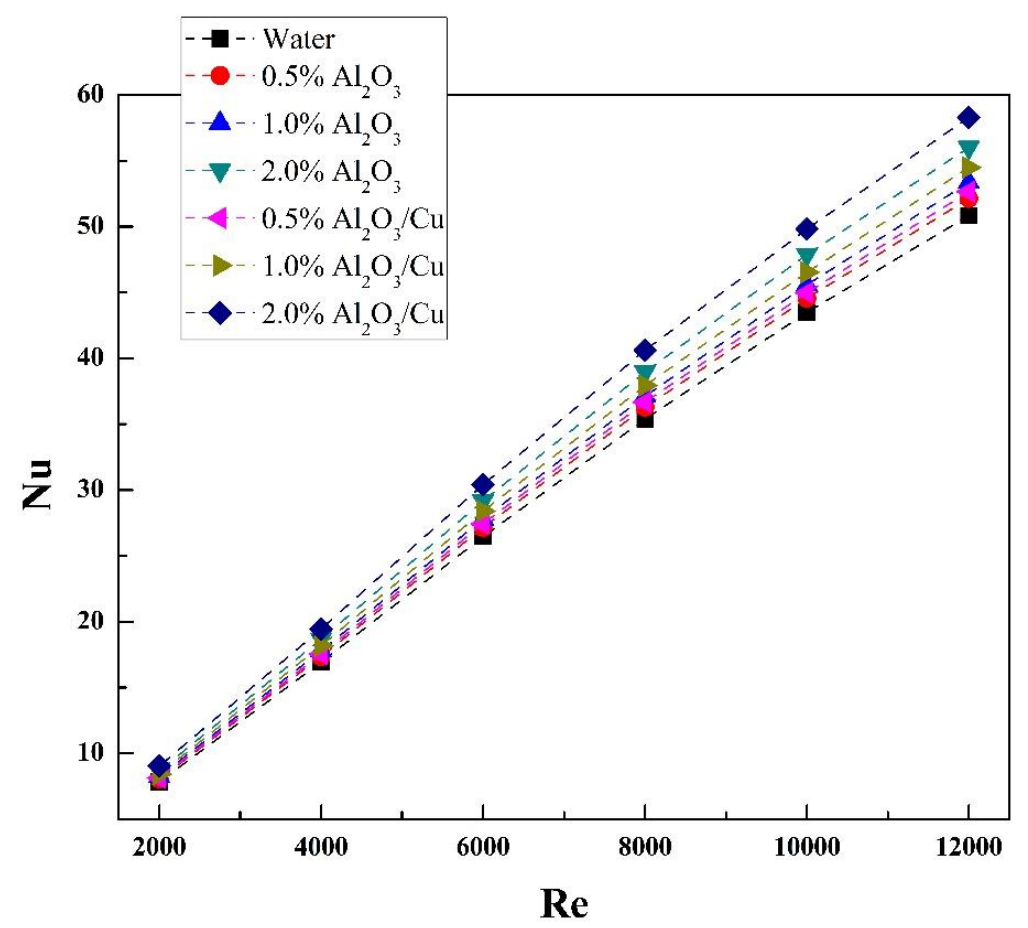

Figure 5. Comparison of Nusselt number of various working fluids with Reynolds number.

\subsubsection{Friction Factor}

The effect of Reynolds number and volume fraction on friction factor of water, single particle and hybrid nanofluids is shown in Figure 7. The friction factor is affected by the pressure drop and velocity of working fluid. Therefore, the variation trend of friction factor for various working fluids are not same as of pressure drop. The considered Reynolds number range shows the transition from laminar to turbulent regime which results into parabolic variation trend of friction factor with Reynolds number for all working fluids. The friction factor increases up to the Reynolds number of 6000 and decreases beyond this value for all working fluids as can be seen from Figure 7. There is a critical Reynolds number below which the friction factor increases with increase in the Reynolds number due to change of flow from laminar to transition regime and above critical Reynolds number, the friction factor decreases with increase in the Reynolds number because of change of flow from transition to turbulent regime. However, it is important to note that the critical point (Re:6000) for friction factor variation over the Reynolds number is not same as commonly suggested Reynolds number for transition of flow to turbulent (Re:4000). The reason for different critical point of friction factor than commonly suggested is dependency of friction factor on ratio of pressure drop to square of velocity as presented 
by Equation (21). Kristiawan et al. have presented the parabolic variation of friction factor with Reynolds number, the friction factor increases up to the critical Reynolds number of 5000 then decreases as the Reynolds number increases beyond the critical value [8]. Kaood et al. have also presented the non-linear trend of the friction factor with Reynolds number, the friction factor decreases as the Reynolds number increases in the turbulent regime [16]. The friction factors of single particle and hybrid nanofluids are higher than water which are increasing with increase in the volume fraction. This is because of higher viscosity of single particle and hybrid nanofluids compared to water which continuously increases with volume fraction. The density of the hybrid nanofluid is higher than the density of single particle nanofluid which results into lower velocity of hybrid nanofluid compared with single particle nanofluid. Therefore, the ratio of pressure drop to square of velocity the hybrid nanofluid shows higher friction factor than single particle nanofluid at the same volume fraction. Despite of lower pressure drop for hybrid nanofluid than single particle nanofluid, the higher density has caused higher friction factor. The friction factors of $0.5 \% \mathrm{Al}_{2} \mathrm{O}_{3}, 1.0 \% \mathrm{Al}_{2} \mathrm{O}_{3}, 2.0 \% \mathrm{Al}_{2} \mathrm{O}_{3}, 0.5 \% \mathrm{Al}_{2} \mathrm{O}_{3} / \mathrm{Cu}, 1.0 \% \mathrm{Al}_{2} \mathrm{O}_{3} / \mathrm{Cu}$ and $2.0 \%$ $\mathrm{Al}_{2} \mathrm{O}_{3} / \mathrm{Cu}$ nanofluids are higher by $1.5 \%, 2.9 \%, 5.9 \%, 2.6 \%, 5.2 \%$ and $10.3 \%$, respectively compared to water. The $2.0 \% \mathrm{Al}_{2} \mathrm{O}_{3} / \mathrm{Cu}$ nanofluid shows highest value of friction factor among all working fluids. The friction factor of $2.0 \% \mathrm{Al}_{2} \mathrm{O}_{3} / \mathrm{Cu}$ nanofluid increases by $1.9 \%$ as the Reynolds number increases from 2000 to 12,000. Firoozi et al. have also presented the friction factor variation range from 0.02 to 0.14 for the maximum Reynolds number variation up to 5000 [3].

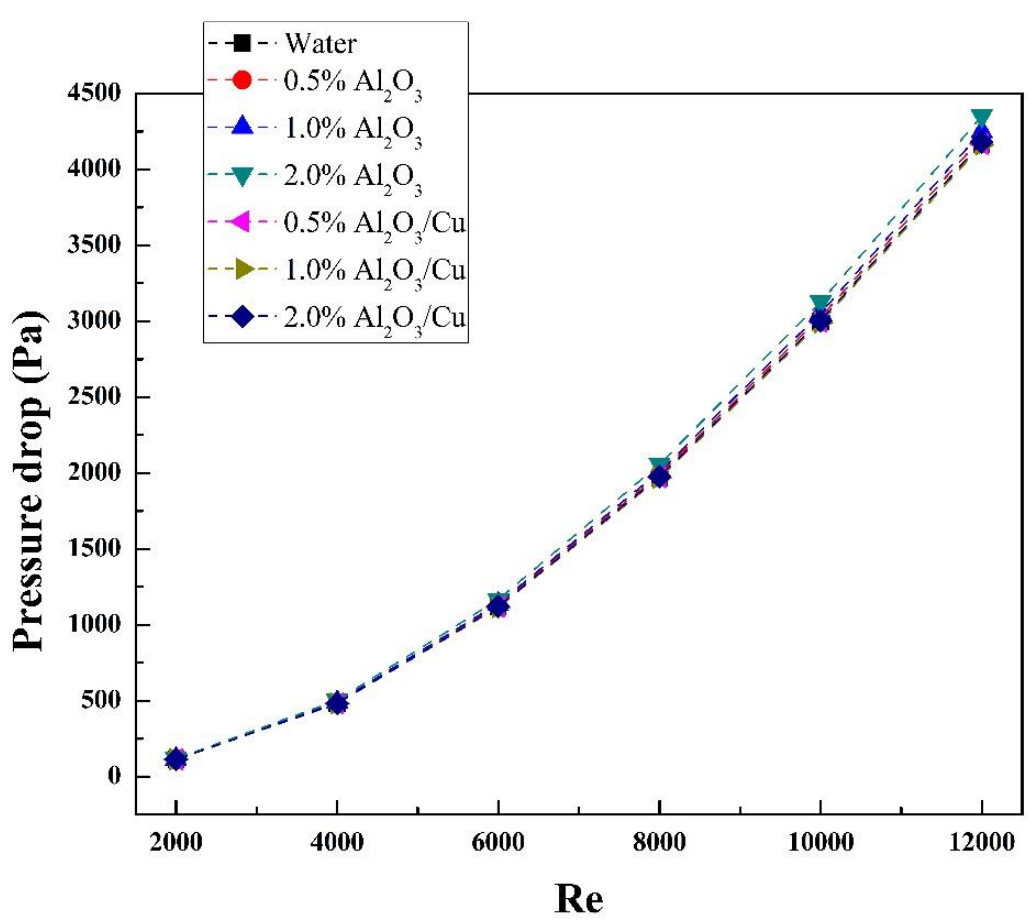

Figure 6. Variation of pressure drop for water, single particle and hybrid nanofluids with various volume fractions and Reynolds number.

\subsubsection{Performance Evaluation Criteria}

The performance evaluation criteria present the combined effect of thermal and flow characteristics because it is calculated based on the Nusselt numbers and friction factors of water and single particle and hybrid nanofluids. The comparison of performance evaluation criteria (PEC) for single particle and hybrid nanofluids with various volume fractions and Reynolds number is depicted in Figure 8. The effect of Reynolds number on the performance evaluation criteria of single particle and hybrid nanofluids is very small. This is because both Nusselt number and friction factor are affected significantly due to variation in Reynolds number. Hence, the overall effect of Reynolds number on 
performance evaluation criteria is nullified. The Nusselt number and friction factor have improved with increase in volume fraction of single particle and hybrid nanofluids as a result of improvement in the thermophysical properties. Therefore, the performance evaluation criteria enhance for both single particle and hybrid nanofluids as volume fraction increases. Azmi et al. have proved that the variation in the performance evaluation criteria is very small and non-linear with Reynolds number. In addition, the performance evaluation criteria increase with increase in volume fraction of nanoparticles [24]. The performance evaluation criteria for hybrid nanofluid are superior compared to single particle nanofluid for the same volume fraction because the increase in the Nusselt number is highly dominant compared to the increase in the friction factor for hybrid nanofluid. The $0.5 \% \mathrm{Al}_{2} \mathrm{O}_{3}$ nanofluid presents the lowest value of performance evaluation criteria and $2.0 \% \mathrm{Al}_{2} \mathrm{O}_{3} / \mathrm{Cu}$ nanofluid presents the highest value of performance evaluation criteria among all nanofluids. Compared to the performance evaluation criteria of $0.5 \% \mathrm{Al}_{2} \mathrm{O}_{3}$ nanofluid, the performance evaluation criteria of $1.0 \% \mathrm{Al}_{2} \mathrm{O}_{3}, 2.0 \% \mathrm{Al}_{2} \mathrm{O}_{3}, 0.5 \% \mathrm{Al}_{2} \mathrm{O}_{3} / \mathrm{Cu}$, $1.0 \% \mathrm{Al}_{2} \mathrm{O}_{3} / \mathrm{Cu}$ and $2.0 \% \mathrm{Al}_{2} \mathrm{O}_{3} / \mathrm{Cu}$ nanofluids are higher by $1.9 \%, 5.9 \%, 0.7 \%, 3.3 \%$ and $8.9 \%$, respectively. Overall, $2.0 \% \mathrm{Al}_{2} \mathrm{O}_{3} / \mathrm{Cu}$ nanofluid with composition of $50 / 50 \%$ has presented the superior heat transfer characteristics among all working fluids. The $2.0 \%$ $\mathrm{Al}_{2} \mathrm{O}_{3}$ nanofluid in single particle case and $2.0 \% \mathrm{Al}_{2} \mathrm{O}_{3} / \mathrm{Cu}$ nanofluids in hybrid case present the superior performances in the respective groups. Therefore, the simulated contours of temperature and velocity for water, $2.0 \% \mathrm{Al}_{2} \mathrm{O}_{3}$ single particle nanofluid and $2.0 \% \mathrm{Al}_{2} \mathrm{O}_{3} / \mathrm{Cu}$ hybrid nanofluid with composition of $50 / 50 \%$ are depicted in Figure 9. The most important section to observe the behavior of simulated results is the outlet of tube. Therefore, the temperature and velocity contours are presented for the working fluid domain at the tube outlet cross section considering the Reynolds numbers of 2000 and 12,000 . As can be seen from Figure 9, the distribution of temperature and velocity contours at the outlet section of tube are symmetrical for water and nanofluids. The heat transfer characteristics of $2.0 \% \mathrm{Al}_{2} \mathrm{O}_{3} / \mathrm{Cu}$ nanofluid is further investigated with additional two compositions of $75 / 25 \%$ and $25 / 75 \%$ and compared with composition of $50 / 50 \%$ as well as water and $2.0 \% \mathrm{Al}_{2} \mathrm{O}_{3}$ nanofluid.

\subsection{Hybrid Nanofluid with Different Compositions}

The comparison of heat transfer characteristics of water, $2.0 \% \mathrm{Al}_{2} \mathrm{O}_{3}, 2.0 \% \mathrm{Al}_{2} \mathrm{O}_{3} / \mathrm{Cu}$ $(50 / 50 \%), 2.0 \% \mathrm{Al}_{2} \mathrm{O}_{3} / \mathrm{Cu}(75 / 25 \%)$ and $2.0 \% \mathrm{Al}_{2} \mathrm{O}_{3} / \mathrm{Cu}(25 / 75 \%)$ is presented in this section. The variation of heat transfer coefficient, Nusselt number, pressure drop, friction factor and performance evaluation criteria with various Reynolds number for above considered working fluids is presented in Figure 10. The heat transfer coefficient and Nusselt number of various working fluid have increased linearly with Reynolds number. This is because of increase in turbulence at higher Reynolds number has resulted into higher heat transfer rate. The hybrid nanofluids with all compositions show higher heat transfer coefficient and Nusselt number than single particle nanofluid and water. This is because of superior thermal conductivity and heat transfer performance of the single particle and hybrid nanofluids compared to water. The increase in the heat transfer coefficient and Nusselt number of hybrid nanofluid enhances with higher portion of $\mathrm{Cu}$ nanoparticle than $\mathrm{Al}_{2} \mathrm{O}_{3}$ nanoparticle because the thermal conductivity of $\mathrm{Cu}$ nanoparticle is superior to $\mathrm{Al}_{2} \mathrm{O}_{3}$ nanoparticle. This means $2.0 \% \mathrm{Al}_{2} \mathrm{O}_{3} / \mathrm{Cu}(25 / 75 \%)$ nanofluid presents highest values of heat transfer coefficient and Nusselt number followed by $2.0 \% \mathrm{Al}_{2} \mathrm{O}_{3} / \mathrm{Cu}(50 / 50 \%), 2.0 \% \mathrm{Al}_{2} \mathrm{O}_{3} / \mathrm{Cu}$ (75/25\%), 2.0\% $\mathrm{Al}_{2} \mathrm{O}_{3}$ nanofluids and water, respectively. The heat transfer coefficient enhances by $546.4 \%$ and Nusselt number increases from 9.14 to 59.09 for $2.0 \% \mathrm{Al}_{2} \mathrm{O}_{3} / \mathrm{Cu}$ $(25 / 75 \%)$ nanofluid with increase in the Reynolds number from 2000 to 12,000 . The heat transfer coefficients of $2.0 \% \mathrm{Al}_{2} \mathrm{O}_{3}, 2.0 \% \mathrm{Al}_{2} \mathrm{O}_{3} / \mathrm{Cu}(50 / 50 \%), 2.0 \% \mathrm{Al}_{2} \mathrm{O}_{3} / \mathrm{Cu}(75 / 25 \%)$ and $2.0 \% \mathrm{Al}_{2} \mathrm{O}_{3} / \mathrm{Cu}(25 / 75 \%)$ nanofluids are higher by $10.2 \%, 14.8 \%, 13.3 \%$ and $16.3 \%$, respectively compared with water. The water, $2.0 \% \mathrm{Al}_{2} \mathrm{O}_{3}, 2.0 \% \mathrm{Al}_{2} \mathrm{O}_{3} / \mathrm{Cu}(50 / 50 \%), 2.0 \%$ $\mathrm{Al}_{2} \mathrm{O}_{3} / \mathrm{Cu}(75 / 25 \%)$ and $2.0 \% \mathrm{Al}_{2} \mathrm{O}_{3} / \mathrm{Cu}(25 / 75 \%)$ nanofluids show the Nusselt number of $50.83,56.02,58.29,57.48$ and 59.09, respectively at the Reynolds number of 12,000 . The vari- 
ation of pressure drop for various working fluid are not linear but increasing with increase in the Reynolds number. This is because the turbulence has increased with increase in the Reynolds number. The decreasing order of pressure drop is $2.0 \% \mathrm{Al}_{2} \mathrm{O}_{3}, 2.0 \% \mathrm{Al}_{2} \mathrm{O}_{3} / \mathrm{Cu}$ (75/25\%) 2.0\% $\mathrm{Al}_{2} \mathrm{O}_{3} / \mathrm{Cu}(50 / 50 \%)$, water and $2.0 \% \mathrm{Al}_{2} \mathrm{O}_{3} / \mathrm{Cu}(25 / 75 \%)$, respectively. The increase in $\mathrm{Cu}$ nanoparticle portion in hybrid nanofluid composition reduces the pressure drop. The $2.0 \% \mathrm{Al}_{2} \mathrm{O}_{3} / \mathrm{Cu}(25 / 75 \%)$ nanofluid shows the lowest pressure drop among all working fluids. Compared to water, the pressure drops of $2.0 \% \mathrm{Al}_{2} \mathrm{O}_{3}, 2.0 \% \mathrm{Al}_{2} \mathrm{O}_{3} / \mathrm{Cu}$ $(50 / 50 \%)$ and $2.0 \% \mathrm{Al}_{2} \mathrm{O}_{3} / \mathrm{Cu}(75 / 25 \%)$ nanofluids are higher by $4.5 \%, 0.34 \%$ and $2.4 \%$, respectively and pressure drop of $2.0 \% \mathrm{Al}_{2} \mathrm{O}_{3} / \mathrm{Cu}(25 / 75 \%)$ nanofluid is lower by $1.6 \%$. The variation in friction factor of various working fluids is parabolic with Reynolds number due to change of flow regime from laminar to transition and transition to turbulent with critical Reynolds number. The critical Reynolds number is 6000 where the friction factor is maximum for all working fluids. The $2.0 \% \mathrm{Al}_{2} \mathrm{O}_{3} / \mathrm{Cu}(25 / 75 \%)$ nanofluid shows highest friction factor followed by $2.0 \% \mathrm{Al}_{2} \mathrm{O}_{3} / \mathrm{Cu}(50 / 50 \%), 2.0 \% \mathrm{Al}_{2} \mathrm{O}_{3} / \mathrm{Cu}(75 / 25 \%)$, $2.0 \% \mathrm{Al}_{2} \mathrm{O}_{3}$ nanofluids and water respectively in the decreasing order. This is due to higher viscosity as well as higher density of hybrid nanofluids, the density increases as the portion of $\mathrm{Cu}$ nanoparticle increases which results into lower velocity. The friction factors of $2.0 \%$ $\mathrm{Al}_{2} \mathrm{O}_{3}, 2.0 \% \mathrm{Al}_{2} \mathrm{O}_{3} / \mathrm{Cu}(50 / 50 \%), 2.0 \% \mathrm{Al}_{2} \mathrm{O}_{3} / \mathrm{Cu}(75 / 25 \%)$ and $2.0 \% \mathrm{Al}_{2} \mathrm{O}_{3} / \mathrm{Cu}(25 / 75 \%)$ nanofluids are higher by $5.9 \%, 10.3 \%, 8.1 \%$ and $12.5 \%$, respectively compared to water. The performance evaluation criteria of $2.0 \% \mathrm{Al}_{2} \mathrm{O}_{3}, 2.0 \% \mathrm{Al}_{2} \mathrm{O}_{3} / \mathrm{Cu}(50 / 50 \%), 2.0 \% \mathrm{Al}_{2} \mathrm{O}_{3} / \mathrm{Cu}$ $(75 / 25 \%)$ and $2.0 \% \mathrm{Al}_{2} \mathrm{O}_{3} / \mathrm{Cu}(25 / 75 \%)$ nanofluids are affected very less by the variation in the Reynolds number due to significant effect of Reynolds number on both Nusselt number and friction factor. The increase of $\mathrm{Cu}$ nanoparticle portion in composition of hybrid nanofluid has shown significant enhancement in the performance evaluation criteria due to overall improvement in the thermophysical properties of hybrid nanofluid. Compared to $2.0 \% \mathrm{Al}_{2} \mathrm{O}_{3}$ nanofluid, the performance evaluation criteria of $2.0 \% \mathrm{Al}_{2} \mathrm{O}_{3} / \mathrm{Cu}(50 / 50 \%)$, $2.0 \% \mathrm{Al}_{2} \mathrm{O}_{3} / \mathrm{Cu}(75 / 25 \%)$ and $2.0 \% \mathrm{Al}_{2} \mathrm{O}_{3} / \mathrm{Cu}(25 / 75 \%)$ nanofluids have improved by $2.8 \%, 2.1 \%$ and $3.5 \%$, respectively. The $2.0 \% \mathrm{Al}_{2} \mathrm{O}_{3} / \mathrm{Cu}(25 / 75 \%)$ nanofluid presents the highest value of performance evaluation criteria.

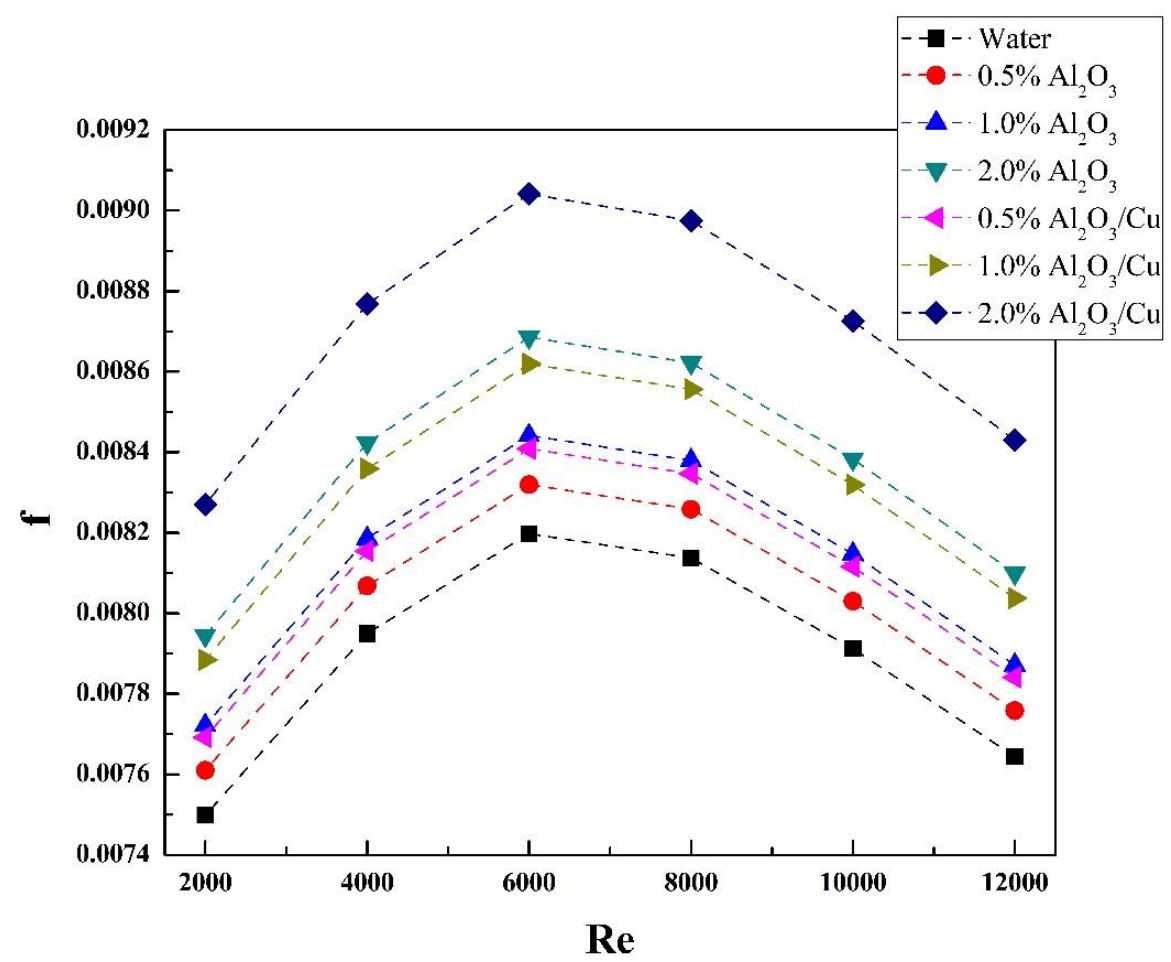

Figure 7. Effect of Reynolds number and volume fraction on friction factor of water, single particle and hybrid nanofluids. 


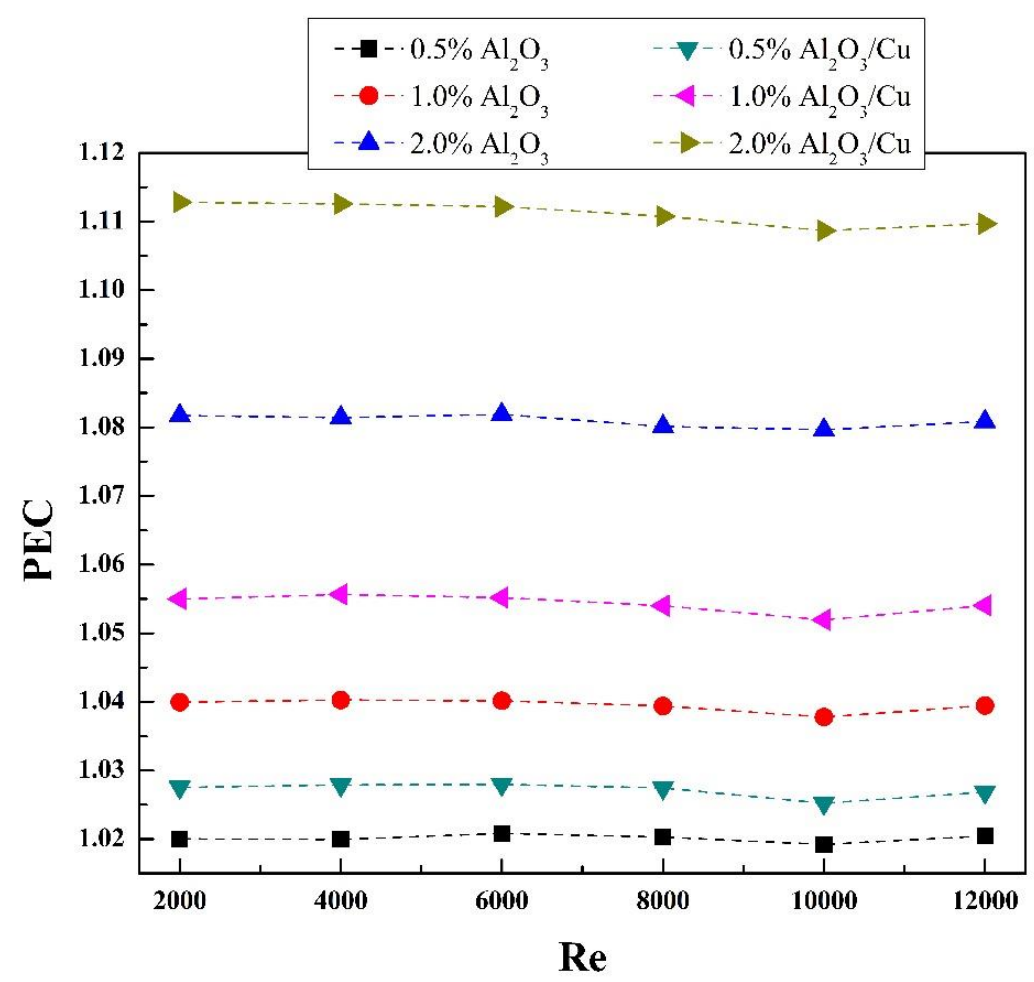

Figure 8. Comparison of performance evaluation criteria for single particle and hybrid nanofluids with various volume fractions and Reynolds number.

Water
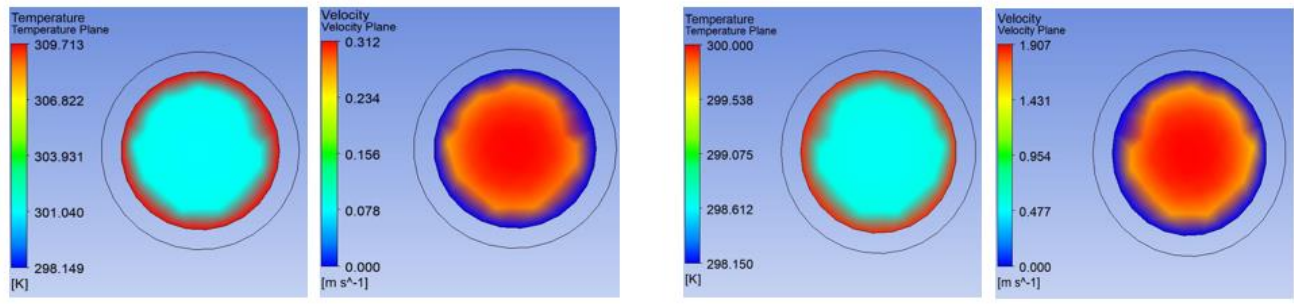

Re: 2000

Re: 12000

$2 \% \mathrm{Al}_{2} \mathrm{O}_{3}$

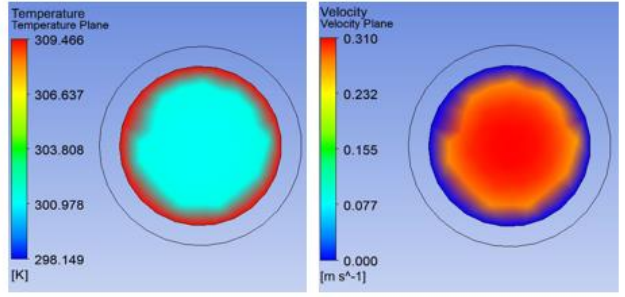

Re: 2000

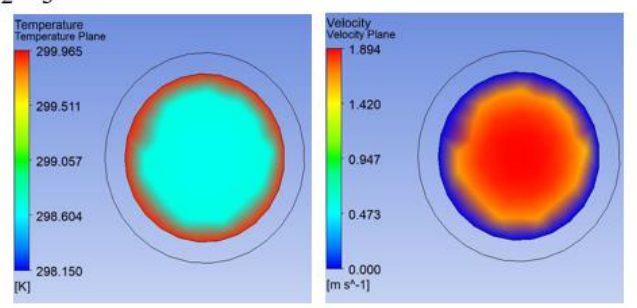

Re: 12000

$2 \% \mathrm{Al}_{2} \mathrm{O}_{3} / \mathrm{Cu}-50 / 50 \%$

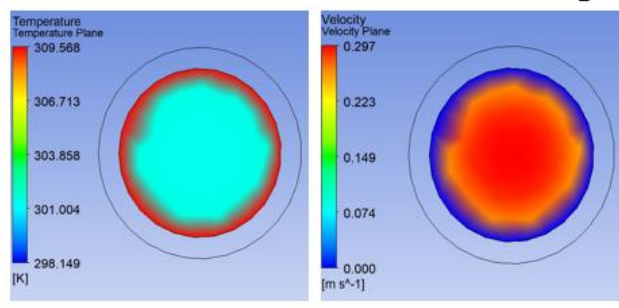

Re: 2000

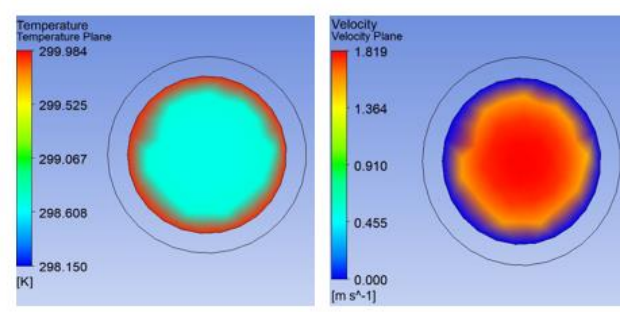

Re: 12000

Figure 9. Temperature and velocity contours for water, $2 \% \mathrm{Al} 2 \mathrm{O} 3$ single particle nanofluid and $2 \%$ Al2O3/Cu hybrid nanofluid with 50/50\% composition at Re:2000 and Re:12,000. 

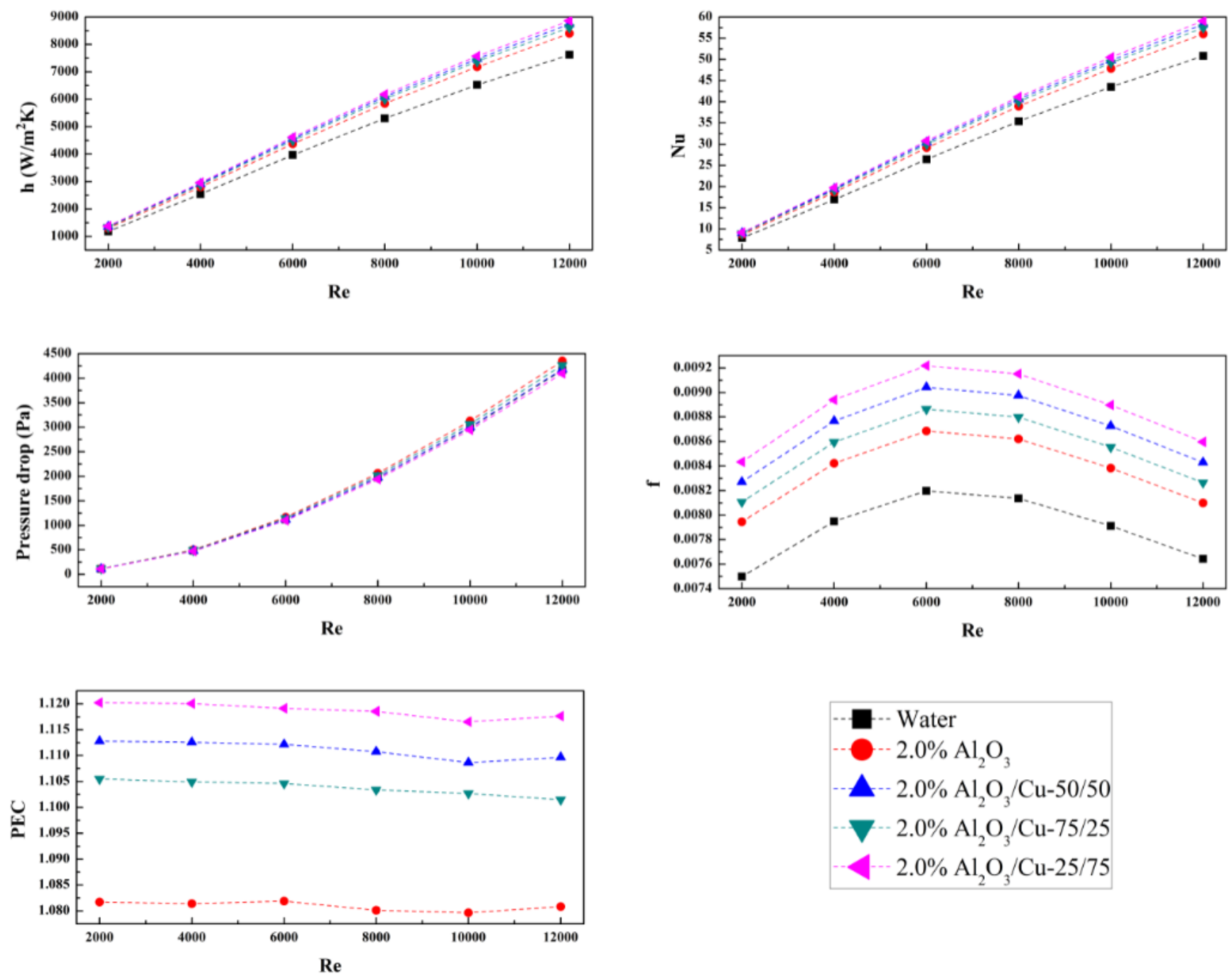

Figure 10. Comparison of heat transfer characteristics of water, $2.0 \% \mathrm{Al}_{2} \mathrm{O}_{3}, 2.0 \% \mathrm{Al}_{2} \mathrm{O}_{3} / \mathrm{Cu}(50 / 50 \%), 2.0 \% \mathrm{Al}_{2} \mathrm{O}_{3} / \mathrm{Cu}$ $(75 / 25 \%)$ and $2.0 \% \mathrm{Al}_{2} \mathrm{O}_{3} / \mathrm{Cu}(25 / 75 \%)$.

\section{Conclusions}

The heat transfer characteristics of water, single particle and hybrid nanofluids in uniformly tube under constant heat flux condition are compared. The heat transfer coefficient, Nusselt number, pressure drop, friction factor and performance evaluation criteria are investigated for various Reynolds number, volume fractions and nanoparticle compositions of hybrid nanofluid. The valuable findings of the present numerical study are summarized as follows.

(a) The heat transfer coefficient and Nusselt number have increased with Reynolds number and volume fraction for single particle and hybrid nanofluids. The heat transfer coefficients of $2.0 \% \mathrm{Al}_{2} \mathrm{O}_{3}$ and $2.0 \% \mathrm{Al}_{2} \mathrm{O}_{3} / \mathrm{Cu}$ nanofluids are higher by $10.2 \%$ and $14.8 \%$, respectively compared to water. The $2.0 \% \mathrm{Al}_{2} \mathrm{O}_{3}$ and $2.0 \% \mathrm{Al}_{2} \mathrm{O}_{3} / \mathrm{Cu}$ nanofluids present Nusselt numbers of 56.02 and 58.29 , respectively.

(b) The pressure drop and friction factor have increased with volume fraction. However, the pressure drop shows increasing trend and friction factor shows parabolic trend with Reynolds number. Compared to water, the $2.0 \% \mathrm{Al}_{2} \mathrm{O}_{3}$ and $2.0 \% \mathrm{Al}_{2} \mathrm{O}_{3} / \mathrm{Cu}$ nanofluids show pressure drops higher by $4.5 \%$ and $0.3 \%$, respectively and those show friction factor higher by $5.9 \%$ and $10.3 \%$, respectively. 
(c) The $0.5 \% \mathrm{Al}_{2} \mathrm{O}_{3}, 1.0 \% \mathrm{Al}_{2} \mathrm{O}_{3}, 2.0 \% \mathrm{Al}_{2} \mathrm{O}_{3}, 0.5 \% \mathrm{Al}_{2} \mathrm{O}_{3} / \mathrm{Cu}, 1.0 \% \mathrm{Al}_{2} \mathrm{O}_{3} / \mathrm{Cu}$ and $2.0 \%$ $\mathrm{Al}_{2} \mathrm{O}_{3} / \mathrm{Cu}$ nanofluids present the performance evaluation criteria of 1.02, 1.04, 1.08, $1.03,1.05$ and 1.11 , respectively.

(d) Addition of higher portion of $\mathrm{Cu}$ nanoparticle in the hybrid nanofluid increases the heat transfer coefficient, Nusselt number, friction factor and performance evaluation criteria and decreases the pressure drop. The $2.0 \% \mathrm{Al}_{2} \mathrm{O}_{3}, 2.0 \% \mathrm{Al}_{2} \mathrm{O}_{3} / \mathrm{Cu}(50 / 50 \%)$, $2.0 \% \mathrm{Al}_{2} \mathrm{O}_{3} / \mathrm{Cu}(75 / 25 \%)$ and $2.0 \% \mathrm{Al}_{2} \mathrm{O}_{3} / \mathrm{Cu}(25 / 75 \%)$ present performance evaluation criteria of $1.08,1.11,1.10$ and 1.12 , respectively.

(e) Based on the numerical results, the best nanofluids could be prepared and used in the plain straight tube to extract the excellent experimental output results. The proposed plain straight tube incorporated with nanofluid flow could be used as an efficient solar receiver tubes to achieve the superior heat transfer performances.

Author Contributions: Conceptualization, K.S.G.; and M.-Y.L.; methodology, K.S.G.; and M.-Y.L.; formal analysis, K.S.G.; and M.-Y.L.; investigation, K.S.G.; and M.-Y.L.; resources, K.S.G.; and M.-Y.L.; data curation, K.S.G.; validation, K.S.G.; software, K.S.G.; writing—original draft preparation, K.S.G.; and M.-Y.L.; writing—review and editing, K.S.G.; and M.-Y.L.; visualization, K.S.G.; and M.-Y.L.; supervision, M.-Y.L.; project administration, M.-Y.L.; funding acquisition, M.-Y.L. All authors have read and agreed to the published version of the manuscript.

Funding: This research received no external funding.

Institutional Review Board Statement: Not applicable.

Informed Consent Statement: Not applicable.

Data Availability Statement: The data presented in this study will be available on request to the corresponding author.

Acknowledgments: This work was supported by the National Research Foundation of Korea (NRF) grant funded by the Korea government (MSIT) (No. 2020R1A2C1011555).

Conflicts of Interest: The authors declare no conflict of interest.

\section{References}

1. Dadhich, M.; Prajapati, O.S.; Sharma, V. Investigation of boiling heat transfer of titania nanofluid flowing through horizontal tube and optimization of results utilizing the desirability function approach. Powder Technol. 2021, 378, 104-123. [CrossRef]

2. Sheikh, N.A.; Ching, D.L.C.; Khan, I. A Comprehensive review on theoretical aspects of nanofluids: Exact solutions and analysis. Symmetry 2020, 12, 725. [CrossRef]

3. Firoozi, A.; Majidi, S.; Ameri, M. A numerical assessment on heat transfer and flow characteristics of nanofluid in tubes en-hanced with a variety of dimple configurations. Therm. Sci. Eng. Prog. 2020, 19, 100578. [CrossRef]

4. Ledari, B.H.; Sabzpooshani, M.; Khayat, M. An experimental investigation on the thermo-hydraulic properties of $\mathrm{CuO}$ and $\mathrm{Fe}_{3} \mathrm{O}_{4}$ oil-based nanofluids in inclined U-tubes: A comparative study. Powder Technol. 2021, 379, 191-202. [CrossRef]

5. Chaurasia, S.R.; Sarviya, R. Comparative thermal performance analysis with entropy generation on helical screw insert in tube with number of strips with nanofluid at laminar flow regime. Int. Commun. Heat Mass Transf. 2021, 122, 105138. [CrossRef]

6. Ying, Z.; He, B.; Su, L.; Kuang, Y.; He, D.; Lin, C. Convective heat transfer of molten salt-based nanofluid in a receiver tube with non-uniform heat flux. Appl. Eng. 2020, 181, 115922. [CrossRef]

7. Saedodin, S.; Zaboli, M.; Rostamian, S.H. Effect of twisted turbulator and various metal oxide nanofluids on the thermal performance of a straight tube: Numerical study based on experimental data. Chem. Eng. Process. Process. Intensif. 2020, 158, 108106. [CrossRef]

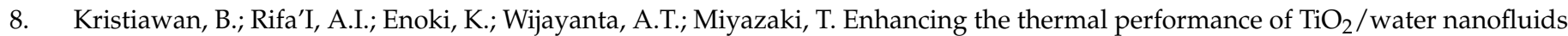
flowing in a helical microfin tube. Powder Technol. 2020, 376, 254-262. [CrossRef]

9. Tiwari, A.K.; Javed, S.; Oztop, H.F.; Said, Z.; Pandya, N.S. Experimental and numerical investigation on the thermal per-formance of triple tube heat exchanger equipped with different inserts with $\mathrm{WO}_{3}$ /water nanofluid under turbulent condition. Int. J. Therm. Sci. 2021, 164, 106861. [CrossRef]

10. Shahsavar, A.; Jha, P.; Arıc1, M.; Estellé, P. Experimental investigation of the usability of the rifled serpentine tube to improve energy and exergy performances of a nanofluid-based photovoltaic/thermal system. Renew. Energy 2021, 170, 410-425. [CrossRef]

11. Mukherjee, S.; Jana, S.; Mishra, P.C.; Chaudhuri, P.; Chakrabarty, S. Experimental investigation on thermo-physical properties and subcooled flow boiling performance of $\mathrm{Al}_{2} \mathrm{O}_{3}$ /water nanofluids in a horizontal tube. Int. J. Sci. 2021, 159, 106581. [CrossRef] 
12. Heyhat, M.; Jafarzad, A.; Changizi, P.; Asgari, H.; Valizade, M. Experimental research on the performance of nanofluid flow through conically coiled tubes. Powder Technol. 2020, 370, 268-277. [CrossRef]

13. Ho, C.; Cheng, C.-Y.; Yang, T.-F.; Rashidi, S.; Yan, W.-M. Experimental study on cooling performance of nanofluid flow in a horizontal circular tube. Int. J. Heat Mass Transf. 2021, 169, 120961. [CrossRef]

14. Sun, B.; Lei, W.; Yang, D. Flow and convective heat transfer characteristics of $\mathrm{Fe}_{2} \mathrm{O}_{3}$-water nanofluids inside copper tubes. Int. Commun. Heat Mass Transf. 2015, 64, 21-28. [CrossRef]

15. Behzadnia, H.; Jin, H.; Najafian, M.; Hatami, M. Geometry optimization for a rectangular corrugated tube in supercritical water reactors (SCWRs) using alumina-water nanofluid as coolant. Energy 2021, 221, 119850. [CrossRef]

16. Kaood, A.; Hassan, M.A. Thermo-hydraulic performance of nanofluids flow in various internally corrugated tubes. Chem. Eng. Process. Process. Intensif. 2020, 154, 108043. [CrossRef]

17. Safaei, M.R.; Mahian, O.; Garoosi, F.; Hooman, K.; Karimipour, A.; Kazi, S.N.; Gharehkhani, S. Investigation of micro- and nanosized particle erosion in a $90^{\circ}$ pipe bend using a two-phase discrete phase model. Sci. World J. 2014, 2014, 1-12. [CrossRef]

18. Amer Qureshi, M. Numerical simulation of heat transfer flow subject to mhd of williamson nanofluid with thermal ra-diation. Symmetry 2021, 13, 10. [CrossRef]

19. Yıldırım, E.; Yurddaş, A. Assessments of thermal performance of hybrid and mono nanofluid U-tube solar collector system. Renew. Energy 2021, 171, 1079-1096. [CrossRef]

20. Saleh, B.; Sundar, L.S. Entropy generation and exergy efficiency analysis of ethylene glycol-water based nanodiamond $+\mathrm{Fe}_{3} \mathrm{O}_{4}$ hybrid nanofluids in a circular tube. Powder Technol. 2021, 380, 430-442. [CrossRef]

21. Ramadhan, A.; Azmi, W.; Mamat, R.; Hamid, K. Experimental and numerical study of heat transfer and friction factor of plain tube with hybrid nanofluids. Case Stud. Eng. 2020, 22, 100782. [CrossRef]

22. Han, Z.; Zhou, W.; Yu, W.; Jia, Z. Experimental investigation on heat transfer of n-decane-ZnO nanofluids in a horizontal tube under supercritical pressure. Int. Commun. Heat Mass Transf. 2021, 121, 105108. [CrossRef]

23. Akbar, H.M.; Mohammed, A.S.; Ezzat, S.B. Hybrid. Nanofluid to Improve Heat Transfer and Pressure Drop through Horizontal Tube; Elsevier BV: Amsterdam, The Netherlands, 2021; Volume 42, pp. 1885-1888.

24. Azmi, W.; Hamid, K.A.; Ramadhan, A.; Shaiful, A. Thermal hydraulic performance for hybrid composition ratio of $\mathrm{TiO}_{2}-\mathrm{SiO}_{2}$ nanofluids in a tube with wire coil inserts. Case Stud. Eng. 2021, 25, 100899. [CrossRef]

25. Moldoveanu, G.M.; Huminic, G.; Minea, A.A.; Huminic, A. Experimental study on thermal conductivity of stabilized $\mathrm{Al}_{2} \mathrm{O}_{3}$ and $\mathrm{SiO}_{2}$ nanofluids and their hybrid. Int. J. Heat Mass Transf. 2018, 127, 450-457. [CrossRef]

26. Yang, C.; Wu, X.; Zheng, Y.; Qiu, T. Heat transfer performance assessment of hybrid nanofluids in a parallel channel under identical pumping power. Chem. Eng. Sci. 2017, 168, 67-77. [CrossRef]

27. Minea, A.A. Hybrid nanofluids based on $\mathrm{Al}_{2} \mathrm{O}_{3}, \mathrm{TiO}_{2}$ and $\mathrm{SiO}_{2}$ : Numerical evaluation of different approaches. Int. J. Heat Mass Transf. 2017, 104, 852-860. [CrossRef]

28. Patil, M.S.; Seo, J.-H.; Lee, M.-Y. Numerical study on geometric parameter effects of power generation performances for segmented thermoelectric generator. Int. J. Air Cond. Refrig. 2018, 26, 1850004. [CrossRef]

29. Seo, J.H.; Garud, K.S.; Lee, M.Y. Grey relational based Taguchi analysis on thermal and electrical performances of thermoe-lectric generator system with inclined fins hot heat exchanger. Appl. Therm. Eng. 2021, 184, 116279. [CrossRef]

30. Hamid, K.A.; Azmi, W.; Nabil, M.; Mamat, R. Experimental investigation of nanoparticle mixture ratios on $\mathrm{TiO}_{2}-\mathrm{SiO}_{2}$ nanofluids heat transfer performance under turbulent flow. Int. J. Heat Mass Transf. 2018, 118, 617-627. [CrossRef]

31. Lee, M.-Y.; Seo, J.-H.; Lee, H.-S.; Garud, K.S. Power generation, efficiency and thermal stress of thermoelectric module with leg geometry, material, segmentation and two-stage arrangement. Symmetry 2020, 12, 786. [CrossRef]

32. Garud, K.S.; Seo, J.-H.; Cho, C.-P.; Lee, M.-Y. Artificial neural network and adaptive neuro-fuzzy interface system modelling to predict thermal performances of thermoelectric generator for waste heat recovery. Symmetry 2020, 12, 259. [CrossRef]

33. Dadsetani, R.; Sheikhzadeh, G.A.; Safaei, M.R.; Leon, A.S.; Goodarzi, M. Cooling enhancement and stress reduction opti-mization of disk-shaped electronic components using nanofluids. Symmetry 2020, 12, 931. [CrossRef]

34. Minea, A.A. Challenges in hybrid nanofluids behavior in turbulent flow: Recent research and numerical comparison. Renew. Sustain. Energy Rev. 2017, 71, 426-434. [CrossRef]

35. Garud, K.S.; Seo, J.-H.; Patil, M.S.; Bang, Y.-M.; Pyo, Y.-D.; Cho, C.-P.; Lee, M.-Y. Thermal-electrical-structural performances of hot heat exchanger with different internal fins of thermoelectric generator for low power generation application. J. Anal. Calorim. 2021, 143, 387-419. [CrossRef]

36. Al-Baghdadi, M.A.S.; Noor, Z.M.; Zeiny, A.; Burns, A.; Wen, D. CFD analysis of a nanofluid-based microchannel heat sink. Sci. Eng. Prog. 2020, 20, 100685. [CrossRef]

37. Devakki, B.; Thomas, S. Experimental Investigation on absorption performance of nanofluids for $\mathrm{CO}_{2}$ capture. Int. J. Air Cond. Refrig. 2020, 28, 2050017. [CrossRef]

38. Kim, M.B.; Park, H.G.; Park, C.Y. Change of thermal conductivity and cooling performance for water based $\mathrm{Al}_{2} \mathrm{O}_{3}-\mathrm{surfactant}$ nanofluid with time lapse. Int. J. Air Cond. Refrig. 2018, 26, 1850009. [CrossRef]

39. Sanches, M.; Marseglia, G.; Ribeiro, A.P.; Moreira, A.L.; Moita, A.S. Nanofluids characterization for spray cooling appli-cations. Symmetry 2021, 13, 788. [CrossRef]

40. Ghachem, K.; Aich, W.; Kolsi, L. Computational analysis of hybrid nanofluid enhanced heat transfer in cross flow micro heat exchanger with rectangular wavy channels. Case Stud. Eng. 2021, 24, 100822. [CrossRef] 
41. Kwon, J.-T.; Nahm, T.-H.; Kim, T.-W.; Kwon, Y.-C. An Experimental study on pressure drop and heat transfer coefficient of laminar ag nanofluid flow in mini-tubes. J. Korea Acad. Coop. Soc. 2009, 10, 3525-3532. [CrossRef]

42. Bhattad, A.; Sarkar, J.; Ghosh, P. Energy-economic analysis of plate evaporator using brine-based hybrid nanofluids as secondary refrigerant. Int. J. Air Cond. Refrig. 2018, 26, 1850003. [CrossRef]

43. Garud, K.S.; Seo, J.H.; Lee, M.Y. Effect of guide fin structures and boundary parameters on thermal performances of heat exchanger for waste heat recovery thermoelectric generator. J. Korea Acad. Ind. 2021, 22, 30-35.

44. Singh, S.K.; Sarkar, J. Thermohydraulic behavior of concentric tube heat exchanger inserted with conical wire coil using mono/hybrid nanofluids. Int. Commun. Heat Mass Transf. 2021, 122, 105134. [CrossRef]

45. Torii, S.; Yoshino, H.; Hajime, Y. Effect of aqueous suspension of graphene-oxide nanoparticles on thermal fluid flow transport in circular tube. Int. J. Air-Cond. Refrig. 2015, 23, 1550005. [CrossRef] 